DIW BERLIN

Discussion

Papers
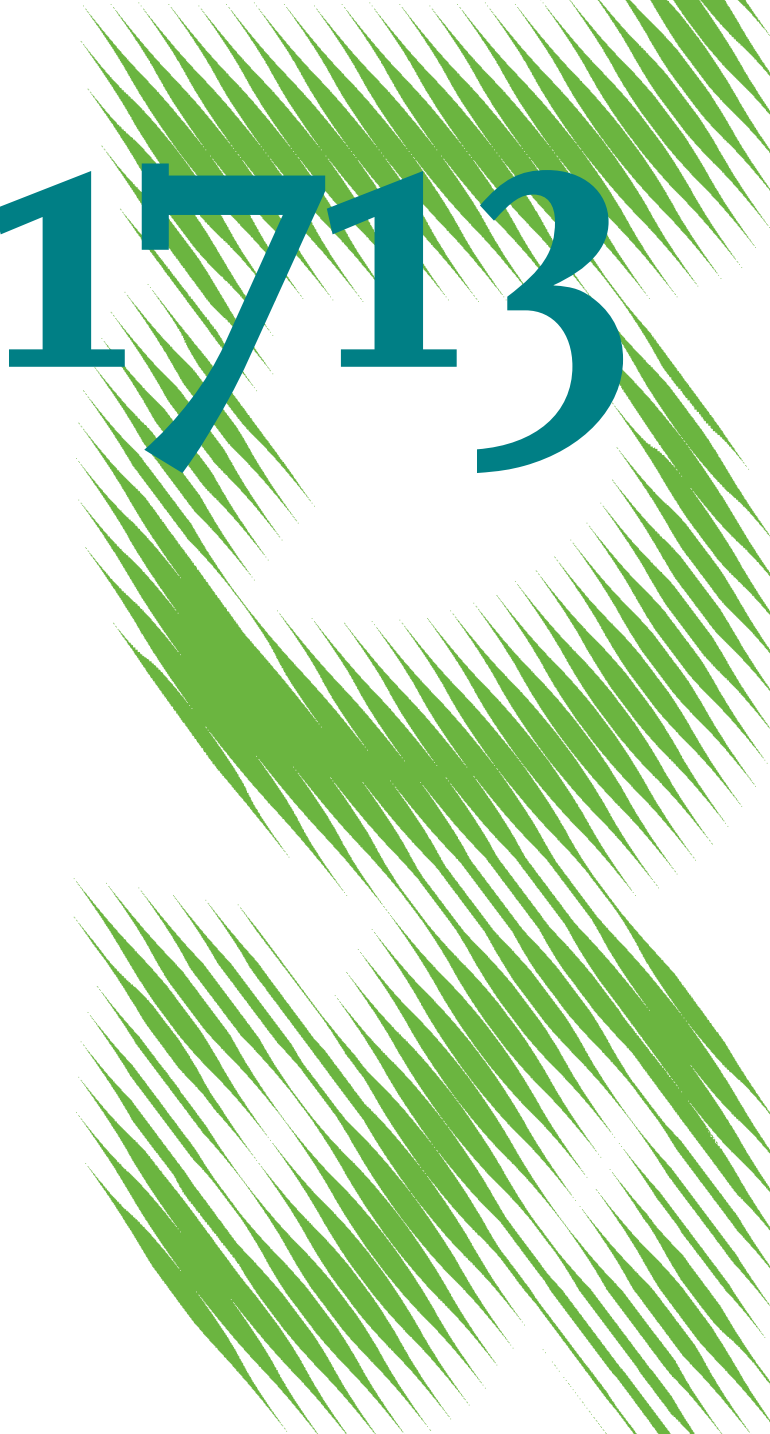

Modern Public Enterprises:

Organisational Innovation and

Productivity 
Opinions expressed in this paper are those of the author(s) and do not necessarily reflect views of the institute.

IMPRESSUM

(C) DIW Berlin, 2017

DIW Berlin

German Institute for Economic Research

Mohrenstr. 58

10117 Berlin

Tel. +49 (30) $89789-0$

Fax +49 (30) $89789-200$

http://www.diw.de

ISSN electronic edition 1619-4535

Papers can be downloaded free of charge from the DIW Berlin website:

http://www.diw.de/discussionpapers

Discussion Papers of DIW Berlin are indexed in RePEc and SSRN:

http://ideas.repec.org/s/diw/diwwpp.html

http://www.ssrn.com/link/DIW-Berlin-German-Inst-Econ-Res.html 


\title{
Modern Public Enterprises: Organisational Innovation and Productivity ${ }^{1}$
}

\author{
Caroline Stiel ${ }^{2}$
}

December 20, 2017

\begin{abstract}
In advanced economies, state-owned enterprises play an important role in sectors of general interest such as energy and water supply. The conditions under which they operate have changed fundamentally since 1998, with new strategies required for firms to preserve market shares in the face of liberalisation and technological innovation. This paper investigates the productivity effect of three strategies in new public management: corporatisation, outsourcing, and partial privatisation. Firm-level productivity is estimated from production data using a control function approach. As most of the firms are typically multiproduct firms, we suggest a method for modelling differences in the product mix and to account for heterogeneous production environments. Using a newly constructed and unique dataset from the German Federal Statistical Office, we find that outsourcing and corporatisation positively impact productivity, while partial privatisation does not increase productivity.
\end{abstract}

JEL Classification: L32, D24, L24, L97

Keywords: State Ownership, Productivity, Firm Organisation, Structural Production Function

1 The author acknowledges financial support from Leibniz Association for the research project KOMIED (Municipal Infrastructure Companies against the Background of Energy Policy and Demographic Change). She would like to thank Astrid Cullmann, Tomaso Duso, Marie Le Mouel, conference participants at the Annual Congress of the German Economic Association (VfS) 2017, AFiD Conference 2017, and seminar participants in Berlin for useful comments and suggestions. The paper uses restricted data that was analysed at the Research Data Centre of the German Federal Statistical Office and the Statistical Offices of the Länder in Berlin. All results were reviewed to ensure that no confidential information is disclosed.

2 German Institute for Economic Research (DIW Berlin), Department Firms and Markets, Mohrenstrasse 58, D-10117 Berlin, Germany. cstiel@diw.de 


\section{Introduction}

Throughout the 20th century, the performance of public enterprises gained a lot of attention in economic literature, with various theoretical contributions discussing incentives, control, and government influence within public firms (Laffont and Tirole, 1991; Vining and Boardman, 1992; Shleifer and Vishny, 1994; Boycko et al., 1996). Using the private sector as a reference point, the major conclusions from this strand of literature were that public firms suffer inherent efficiency problems due to managerial slack, excessive government influence, and weak incentives for innovation.

In line with this rationale, the New Public Management (NPM) movement suggested the introduction of market-oriented practises in the spheres of public administration, which also extends to public service provision (see Hood, 1995; Kettl, 1997, for an overview). To improve efficiency, public enterprises are encouraged to (i) reform their organisational structure towards more autonomy and less direct government influence; (ii) focus on core activities through the use of subcontracting; and (iii) enjoy knowledge spill-overs from joint ventures with the private sector.

The empirical evaluation of public enterprises' new organisational practise, however, is scarce. More fundamentally, Florio (2014) remarks, that „economists and policy-makers no longer seem to have a firm understanding of why PE [public enterprises] exist, what explains their performance, and the role of the State as owner"(p.201). The study of public enterprises seems to have disappeared from economic manuals, signalling definitive obsolescence of the former, which is curiously at odds with the vital role that public enterprises still occupy in advanced economies. Rather, we observe a renaissance of public involvement in economic activities, particularly at the local level (Hall et al., 2013; Cullmann et al., 2016). Thus, understanding the drivers behind public sector performance is essential. Since 1998, public enterprises have had to adapt to market environments which are very different from those of the post-war era. Liberalisation in sectors of general interests, such as telecommunications, postal services, and energy provision, introduced competition between public and private companies. New technologies and demand patterns require new infrastructure and product lines, and call for permanent innovation. Reorganisation and more efficient input usage could be instrumental in successfully managing this transformation.

The present paper investigates the link between organisational innovation and productivity focusing on three elements: (i) corporatisation; (ii) outsourcing; and (iii) partial privatisation ${ }^{3}$, i.e. selling minority shares to the private sector. Performance is measured as total factor productivity derived from a translog production

\footnotetext{
${ }^{3}$ Extending the analysis to fully-privatised firms is unfortunately beyond the scope of this paper due to lack of adequate microdata on the private sector. For an empirical comparison of stateowned and fully privately-owned firms in German electricity supply, see Stiel et al. (2017) and Cullmann et al. (2017).
} 
function and estimated in a novel multiproduct framework following the control function approach developed by Ackerberg et al. (2015). The model is applied to public service provision, analysing German state-owned firms in energy and water supply between 2003 and 2014 .

Our contribution is three-fold. First, we contribute empirical evidence on contemporary public enterprises at the micro-level. For this, we construct the first comprehensive dataset of 2,325 German energy and water firms that are owned by the state using newly available official data. While several cross-country studies exist (e.g., Florio, 2013; Borghi et al., 2016; Clò et al., 2017), firm-level evidence on the performance of European public enterprises is limited. Second, we empirically assess propositions of the New Public Management approach, which has not yet been done in a systematic way. Third, given that German energy and water firms are multiproduct firms, which operate at different stages of the value chain and combine different output products, we suggest a method for accounting for different output and input price levels at the product level.

Results show that corporatisation and outsourcing are positively correlated with productivity, while private sector participation does not increase productivity. Rather, fully state-owned firms outperform those with private minority shareholders.

The paper is structured as follows. Section 3 reviews the relevant literature and section 2 provides some background on the use of NPM strategies among German energy and water firms under state-ownership. After the model and the estimation strategy are explained in sections 4 and 5, the data is introduced in section 6 . Sections 7 and 8 discuss the results and section 9 concludes.

\section{Background}

\subsection{Public utilities}

German energy and water supply is traditionally characterised by strong decentralisation. Most municipalities established their own multi-utilities that provide the local population with electricity, gas, heat, and water (horizontal integration). Many of them integrate production steps from generation to retail (vertical integration). ${ }^{4}$ In 2012, Germany counted roughly 2,000 energy firms and 6,000 water firms (Cullmann et al., 2016; Statistisches Bundesamt, 2015) and public firms co-exist with private and mixed-ownership firms. About half of the energy firms and the vast majority of water firms were majority-owned by local authorities.

\footnotetext{
4 The only exception are conventional electricity generation, electricity transmission and gas transmission, where nationwide private firms dominate the market.
} 


\subsection{Corporatisation}

State-owned energy and water firms can choose between different legal structures. Corporatisation denotes the transition of government organisations under public law to private law companies. This does not change the ownership composition of the firms, i.e., they are still fully state-owned, but affects internal organisation of the firm. The following differences exist between organisations under public law and private law.

Public law. Firms that are fully owned by state authorities may choose to organise under public law and benefit from specific rules in terms of taxation and accounting. Managers' autonomy is usually low in these firms and local politicians can exert direct influence on day-to-day decision making trough membership in advisory boards. Under public law, advisory boards have extensive discretionary power and firms are treated as branches of the local administration. The dataset distinguishes two types of organisations under public law: Eigenbetrieb and Zweckverband. The latter denotes a formal cooperation of pure water utilities from different municipalities.

Private law. State-owned firms organised under private law ('corporatised'), by contrast, resemble private firms. Managers are legally autonomous in daily decision making and local politicians can only decide on general strategies. Corporatised firms can apply private labour law, thus benefiting from greater flexibility (e.g., temporary working contracts). They are subject to the same accounting and taxation rules as private firms. We analyse two forms, Gesellschaft mit beschränkter Haftung $(\mathrm{GmbH})$, which is close to a limited liability company in the British context, and Aktiengesellschaft (AG), which is a stock corporation.

\subsection{Outsourcing}

Subcontracting is widely used among state-owned energy and water firms with a strong focus on knowledge-intensive business services (KIBS, such as IT, marketing, procurement). Since procurement with energy became increasingly complex with the liberalisation of electricity and gas markets, small firms especially tend to rely on external services. Likewise, intensified competition in the retail markets after liberalisation requires more elaborate marketing strategies and the design of a corporate identity.

It is worth noting that external services are not only provided by the private sector. Several state-owned energy and water firms have founded joint ventures that bundle expertise on KIBS and are available both to members and outsiders. Large state-owned firms sell their expertise to other market participants and there is a general network of exchange and consultancy (see, e.g., Trianel, Thüga). 


\section{Related literature}

Outsourcing. The relationship between organisational structure and firm performance is gaining increasing attention. López (2014) stresses that decisions to outsource can be interpreted as a form of organisational innovation. While traditional innovation literature usually focuses on innovation in products and measures the influence of R\&D expenditure on productivity (see, for instance, Aw et al., 2011; Doraszelski and Jaumandreu, 2013), reorganisation within the firm and the decision to subcontract can affect firm performance in an equally fundamental way. For services requiring specific knowledge or on-the-job-training (knowledge-intensive business services such as IT, marketing), internal provision might be inadequate and costly. External suppliers can benefit from a centralisation of expertise and economies of scale (Roodhooft and Warlop, 1999) and offer these services at lower costs and higher quality. Costs of outsourcing, on the other hand, consist in finding reliable suppliers, in monitoring and enforcing contracts and in a loss of strategic flexibility. Windrum et al. (2009) discuss the outsourcing productivity paradox in this regard. While outsourcing should ideally lead to productivity growth in the short term, long-term productivity can be negatively affected. The reason is the lack of investment in knowledge and related human capital. Firms risk becoming locked-in to subcontracting by lack of adequate staff and infrastructure, thus losing flexibility in responding to demand changes and competitors' moves. If asymmetry in knowledge prevents effective monitoring of suppliers' performance, firms could depend on outdated services and technologies, further losing efficiency.

Firm-level evidence on the link between productivity and outsourcing is mostly obtained from the manufacturing sector, with a focus on imports and the consumption of intermediates. Fariñas et al. (2014) and López (2014) investigate subcontracted production over total consumption of intermediates for Spanish manufacturers and observe a positive impact from outsourcing. Antonietti (2016) distinguishes between production outsourcing and service outsourcing. In the case of production outsourcing, there are positive effects for Italian manufacturers if subcontracting is embedded in a broader human resources strategy with simultaneous investment into skills of the established workforce. Antonietti does not find any impact from service outsourcing. Morrison Paul and Yasar (2009) study Turkish textile plants and find that input outsourcing is associated with higher productivity and high-skilled labour use, while output outsourcing is negatively correlated with productivity and skilled-labour intensity. Survey-based studies for Sweden and the US, on the other hand, find no significant impact of outsourcing on various measures of performance (Bengtsson and Dabhilkar, 2009; Gilley and Rasheed, 2000). While evidence for the manufacturing sector is growing, no systematic studies exist for the public sector and the relevance of outsourcing to public enterprise performance is largely unstudied.

Corporatisation. The general approach taken to analysing public sector performance is usually a comparison with the private sector, which establishes a dichotomy 
between two extreme options - privatisation and nationalisation. However, some early contributions already remarked that 'organisation matters'. Public enterprises differ by governance structure and exhibit different degrees of legal autonomy, managerial professionalism, and exposition to financial restrictions (Aharoni, 1981; Estrin and Pérotin, 1991). Bartel and Harrison (2005) conduct an empirical study of Indonesian manufacturers and show that only those public enterprises that had close ties with the government, e.g., through soft budget constraints and trade protection, performed worse than the private sector. Bertero and Rondi (2000) analyse a panel of Italian state-owned manufacturers and find that total factor productivity increased in a period of hard budget constraints. Fumagalli et al. (2007) are close to what is done in this paper. They investigate drivers behind service quality of Italian electricity distributors and consider two aspects: managerial discretion and partial privatisation. They find that service quality is higher for firms with strong external boards but remains unaffected by partial privatisation. Corporatisation, i.e., the transition from government organisations to private-sector-law companies, is usually associated with all of these aspects. Although the number of corporatised public organisations is increasing (e.g. from 38 per cent to 55 per cent between 1990 and 2010 in the German energy sector, Gottschalk, 2012), empirical evaluation of performance changes is missing.

Partial privatisation. Partial privatisation raises the question why private shareholders should be willing to hold minority shares in state firms at all. If state firms were inherently less efficient than private firms, should investments not be directed towards more profitable undertakings? Pargendler et al. (2013) point out that investing in state-owned firms gives access to some privileges such as subsidies, lower cost of debts, implicit government guarantees, and monopolistic rents. Furthermore, governments might sell shares at discount prices or commit to guaranteed dividend schemes in order to attract private sector participation. From the viewpoint of the government, partial privatisation can be valuable in order to raise funds and benefit from knowledge spill-over, improved managerial practise, and access to new technology. This is particularly relevant if shares are not dispersed but sold to competitors from the same industry, which is the case in German energy and water supply.

The conventional reasoning of a positive link between partial privatisation and performance is put into question by the motivation crowding-out literature (see Polidori and Teobaldelli (2013) for a literature review). The main critique is that standard theory completely abstracts from intrinsic motivation, which can be an important source of commitment in the public sector where extrinsic incentives, such as performance-related pay, are low. Studies on prosocial behaviour among civil servants provide evidence for the existence of a public service motivation (Rainey, 1982; Crewson, 1997; Houston, 2000) and for self-selection of intrinsically motivated individuals into the public sector (Gregg et al., 2011). To illustrate the motivation crowding out dilemma, Grönblom and Willner (2014) construct a principal-agent model where privatisation leads to a reduction in managerial effort. They argue 
that the introduction of rigid business principles from private owners could be perceived by public managers as arbitrary top-down control that interferes with their own strategy of countervailing social and profit goals. The mixture of different goals is also discussed in Bénabou and Tirole (2003). Focus on profit maximisation and related performance-pay could distort the manager's effort from the achievement of a more tedious long-term social objective towards an easy measurable goal which produces immediate rewards. ${ }^{5}$ Similarly, mixed enterprises could suffer from a multiple principals problem that adversely affects effort and output level (Laffont and Martimort, 1997).

\section{Model}

Total factor productivity $\omega$ is estimated in a production function framework with the three main inputs of labour $L$, capital $K$, and external services $S$, as well as two intermediate inputs of material $M$, and procured energy and water $E$, and, lastly, an error term $\epsilon$. Total output is denoted by $Q$.

$$
Q=f(L, K, S, M, E) * \exp (\omega+\epsilon)
$$

\subsection{Multiproduct structure and unobserved prices}

\subsubsection{Output}

Since most state-owned energy and water firms are integrated multiproduct firms, total output is difficult to measure in physical terms. We observe total sales at the firm-level and have information on the product space of each firm. However, we observe neither input allocation per product nor the quantity and prices of each product sold. We estimate production at the firm-level, and use the following strategy to account for unobserved input and output prices at the product level. Loglinearising equation (1) gives

$$
q_{i t}=\sum_{J} q_{i j t}=f\left(l_{i t}, k_{i t}, s_{i t}, m_{i t}, e_{i t}\right)+\omega_{i t}+\epsilon_{i t}
$$

\footnotetext{
${ }^{5}$ Francois $(2000,2007)$ offer an interesting revision of the standard residual rights claimant argument. If effort within a public agency is mostly driven by belief that the quality of service provision decreases in case of shirking (as bureaucrats are only weakly interested in profit maximisation and the government owner exerts lose control), genuinely motivated employees will increase their labour donation to offset poorly motivated colleagues. Private firms do not benefit from this voluntary increase in labour as they cannot commit not to adjust other inputs in reaction to reduced effort (e.g., through hiring extra staff). They are residual claimants of the profits that would otherwise be lost.
} 
where firm $i$ is observed in year $t$ and sells product $j .{ }^{6}$ Exploiting the fact that total revenue is calculated from total output times prices, i.e. $R_{i t}=\sum_{J} R_{i j t}=$ $\sum_{j} Q_{i j t} P_{i j t}$, we can formulate the left-hand side as

$$
r_{i t}-\sum_{J} p_{i j t}=f\left(l_{i t}, k_{i t}, s_{i t}, m_{i t}, e_{i t}\right)+\omega_{i t}+\epsilon_{i t} .
$$

Firm-specific product prices $p_{i j t}$ are typically not available. Instead, total revenue $r_{i t}$ of multiproduct firms is usually deflated by some producer price index (PPI) that reflects a weighted sum of products within the industry. ${ }^{7}$ This can be problematic if the firms do not produce the same product mix and if price levels differ significantly between products (see Collard-Wexler and De Loecker (2015) for quantifying the bias). This is the exact case for German energy and water supply, where selling one unit of electricity provides much more revenue than selling one unit of water. Using a global PPI would bias productivity scores downwards for firms that focus on water supply.

We overcome this by assuming that $p_{i j t}=p_{j t}$ but $p_{j t} \neq p_{t}$, i.e. output prices are comparable across firms but large differences exist between sectors. We relax the first assumption later for the electricity sector, i.e. firms can differ in their unit output prices for electricity sold. ${ }^{8}$ The intuition for the assumption is that while minor prices differences may exist between firms, differences between activities are much more pronounced. We can then proxy for the aggregate firm-specific output price in the following way:

$$
p_{i t}=\sum_{J} p_{i j t} \approx \sum_{J} \gamma_{j} \bar{p}_{j t} d_{i j t}
$$

where $\bar{p}_{j t}$ is the PPI for product $j, \gamma_{j}$ is a scaling parameter that captures the price difference relative to all other products $J_{-1}$ and $d_{i j t}$ is a dummy variable characterising the product mix of the firm, i.e., whether firm $i$ sells product $j$ or not. The parameter $\gamma_{j}$ is estimated within the model, while $\bar{p}_{j t}$ is taken from official statistical data and $d_{i j t}$ is observed.

\footnotetext{
${ }^{6}$ The product space is composed of 8 products $J=$ \{electricity sold to residents, electricity sold to business customers including manufacturing, wholesale electricity, electricity distribution, district heat sold to households, district heat sold to non-residents, gas supply, water supply . Information on vertical activities is only available for the electricity sector. However, we argue that this is less important in the remaining sectors for the following reasons. Since water and district heat supply are local monopolies, the majority of water and district heat firms in Germany are vertically integrated. Gas generation plays a minor role in Germany $(<12 \%$ of German gas consumption, BMWi, 2017). For historical reasons, most municipal gas providers also own the distribution networks. Independent gas retailers that entered the market after liberalisation are more commonly found in the private sector.

7 The PPI reflects price changes over time but is uninformative about level differences between prices of the same year.

${ }^{8}$ For the other products, no product-level output price data is available.
} 


\subsubsection{Material}

Similarly, as material input is usually difficult to aggregate in physical terms, material expenditure is used instead. The most important material in energy sectors is the fuel for electricity and heat generation. However, not all firms use the same fuel technology when producing electricity or heat. This may lead to very different input prices for material. Assume instead that all firms face identical fuel prices but differ in the type of fuel they use. Material expenditure $\tilde{m}_{i t}$ is then given by the log sum of material use, fuel prices $p_{f t}$ and the average price of the remaining material inputs $p_{\text {other,t }}$

$$
\tilde{m}_{i t}=m_{i t}+\sum_{F} p_{f t} d_{i f t}+p_{\text {other }, t} .
$$

The dummy variable $d_{i f t}$ characterises the fuel mix of the firm. Those fuel prices for which no price level data is available (e.g. lignite) are proxied as

$$
p_{f t} \approx \gamma_{f} \bar{p}_{f t}
$$

where $\bar{p}_{f t}$ is the PPI for fuel $f$ and $\gamma_{f}$ is a scaling parameter that captures the price difference of fuel $f$ relative to the remaining material input. Parameter $\gamma_{f}$ is estimated within the model, while $\bar{p}_{f t}$ is taken from official statistical data and $d_{\text {ift }}$ is observed.

\subsubsection{Procured energy and water}

Many firms in the utility industry buy parts of the energy and water retailed to end-consumers from third parties (e.g., traders, importers, other utilities). The type of energy or water procured is directly linked to the output portfolio and thus varies across firms. Deflating procured energy and water expenditure $\tilde{E}$ by a global PPI, which assumes a fixed energy mix, would lead to the same problem as on the output side. We argue that this is addressed by the following set of unrestrictive assumptions.

A1 Assume that procured energy and water is a subset of the energy and water sold as outputs, e.g., firms that sell heat and gas buy only heat or gas, but no other products.

A2 Assume that the relative price difference of procured energy types is comparable to the relative price difference on the output side. Likewise, assume that price trends over time mirror those on the output side (same PPI).

Then differences in input structure for procured energy and water are already accounted for in equation (4). 


\subsection{Production environment}

State-owned energy and water firms differ in the production environment. Distribution networks in urban areas tend to connect more people who live closer together, thus providing economies of density to the firm. ${ }^{9}$ The same applies to water retail and district heat supply, which are organised as local monopolies in Germany, such that the firm's customers are identical with the local population. We argue that population density is exogenously given and there is no self-selection into locations for state-owned energy and water firms. ${ }^{10}$ This is a standard assumption in the literature comparing performance of network operators (see, e.g., Kumbhakar and Hjalmarsson, 1998; Kwoka, 2005; Celen, 2013). We approximate population density through settlement type ${ }^{11}$ and model it as an exogenous shock $\xi_{p}$ to output $\tilde{q}_{i t}$

$$
q_{i t}=\tilde{q}_{i t}+\xi_{p}
$$

where $\tilde{q}_{i t}$ is the equilibrium output if all firms operated in the same environment.

\subsection{Summarising the production function}

We model the true underlying production function by a translog function with median-corrected inputs and outputs. The translog function provides more flexibility regarding the elasticities of substitution between input factors and allows output elasticities to vary between firms. It is commonly used for models in the energy and water sectors (Kumbhakar, 1996; Saal et al., 2007; Farsi and Filippini, 2009) and is also applied to productivity estimation (e.g., De Loecker and Warzynski, 2012). The final equation estimates output elasticities and productivity at the firm-level, controlling for different output and input prices at the product level. It is obtained by plugging equations (4) to (7) into the translog production function based on (3)

${ }^{9}$ Economies of density mean that a firm uses the same amount of inputs as another firm but reaches more customers due to its location in a more densely populated area. Both in urban and rural areas, network operators have to build lines to connect newly built facilities (including housing and offices). In a big city, new housing tends to be apartment houses with multiple customers, whereas rural areas are typically characterised by single family homes.

10 They traditionally operate in the geographic area of the owning municipality. Population density plays a minor role in electricity and gas trade, which is open to nation-wide competition, such that firms are not restricted to their own municipality.

${ }^{11}$ The categories are big cities, suburban regions, densely populated rural areas and sparsely populated rural areas, see section 6 for details. 


$$
\begin{aligned}
y_{i t}= & +\beta_{l} l_{i t}+\beta_{s} s_{i t}+\beta_{k} k_{i t}+0.5 \beta_{l l} l_{i t}^{2}+0.5 \beta_{s s} s_{i t}^{2}+0.5 \beta_{k k} k_{i t}^{2} \\
& +\beta_{l s} l_{i t} s_{i t}+\beta_{l k} l_{i t} k_{i t}+\beta_{k s} k_{i t} s_{i t} \\
& -\sum_{F} \gamma_{f} \bar{p}_{f t} d_{i f t}+\sum_{J} \gamma_{j} \bar{p}_{j t} d_{i j t}+\xi_{p} \\
& +\omega_{i t}+\epsilon_{i t} .
\end{aligned}
$$

The left-hand side $y_{i t}$ can be interpreted as the value added composed of $y_{i t}=$ $r_{i t}-\tilde{e}_{i t}-\left(\tilde{m}_{i t}-\bar{p}_{\text {other }, t}\right)$. We assume a stable relationship between output and intermediate goods $\left(e_{i t}, m_{i t}\right)$, but model intermediate services as a flexible input on the right-hand side, thereby allowing its output elasticity to vary over time and between firms. Section 6.3.1 presents more details on the subcontracting of services and show that usage is subject to some important changes over time and between sectors. The dummy $d$ characterises the product mix, i.e. whether a firm sells product $j$ or uses fuel $f$.

\section{Empirical strategy}

The model is estimated using a control function approach based on Ackerberg et al. (2015). The advantage of this approach over other techniques is that it does not require productivity to be exogenous. Rather, productivity may be correlated with input choice. This is quite likely if firms take their own productivity level into account when making input decisions. While the productivity level is known to the firm, it is usually unobservable to the econometrician. Olley and Pakes (1996) are the first to suggest a method for proxying unobservable productivity with the help of a control function.

\subsection{Controlling for unobserved productivity}

The estimation procedure consists of two steps. In the first step, unobservable productivity is backed out using the input demand function of one static, flexible input without adjustment costs. We assume that demand for external services is such a flexible input, i.e. firms can re-negotiate contracts with services providers at least once a year and adjust the level of external services to their current needs. The choice of external services then depends on the level of capital $k_{i t}$ and labour $l_{i t}$ (which are pre-determined ${ }^{12}$ ), productivity, the product mix, the fuel mix, and the production environment

\footnotetext{
$\overline{12}$ Investment into capital is usually long-term oriented and strict union contracts in public services prevent immediate changes to labour force.
} 


$$
s_{i t}=s_{t}\left(l_{i t}, k_{i t}, \omega_{i t}, d_{i j t}, d_{i f t}, \xi_{p}\right) .
$$

If $s_{t}(\cdot)$ is strictly monotone in $\omega_{i t}$, the function can be inverted to obtain an expression for productivity $\omega_{i t}$

$$
\omega_{i t}=h_{t}\left(l_{i t}, k_{i t}, s_{i t}, d_{i j t}, d_{i f t}, \xi_{p}\right) .
$$

Inserting (12) into (8) yields an estimation equation that only depends on observables and the error term $\epsilon_{i t}$

$$
\begin{aligned}
y_{i t}= & c+\beta_{l} l_{i t}+\beta_{s} s_{i t}+\beta_{k} k_{i t}+0.5 \beta_{l l} l_{i t}^{2}+0.5 \beta_{s s} s_{i t}^{2}+0.5 \beta_{k k} k_{i t}^{2} \\
& +\beta_{l s} l_{i t} s_{i t}+\beta_{l k} l_{i t} k_{i t}+\beta_{k s} k_{i t} s_{i t} \\
& -\sum_{F} \gamma_{f} \bar{p}_{f t} d_{i f t}+\sum_{J} \gamma_{j} \bar{p}_{j t} d_{i j t}+\xi_{p} \\
& +h_{t}\left(l_{i t}, k_{i t}, s_{i t}, d_{i j t}, d_{i f t}, \xi_{p}\right)+\epsilon_{i t} .
\end{aligned}
$$

Equation (11) is estimated by OLS, where $h(\cdot)$ is approximated by a polynomial of order 2 . We obtain an (unbiased) prediction $\Phi_{i t}$ which is used to express productivity as

$$
\begin{aligned}
\omega_{i t}(\boldsymbol{\beta}, \boldsymbol{\gamma})= & \Phi_{i t}-c-\beta_{l} l_{i t}-\beta_{s} s_{i t}-\beta_{k} k_{i t}-0.5 \beta_{l l} l_{i t}^{2}-0.5 \beta_{s s} s_{i t}^{2}-0.5 \beta_{k k} k_{i t}^{2}-\beta_{l s} l_{i t} s_{i t} \\
& -\beta_{l k} l_{i t} k_{i t}-\beta_{k s} k_{i t} s_{i t}+\sum_{F} \gamma_{f} \bar{p}_{f t} d_{i f t}-\sum_{J} \gamma_{j} \bar{p}_{j t} d_{i j t}-\xi_{p} .
\end{aligned}
$$

The vector $(\boldsymbol{\beta}, \boldsymbol{\gamma})$ is still biased, since the related variables appear both in the translog production function and in $h_{t}(\cdot)$. This is addressed in the second step of the estimation.

\subsection{Productivity growth through reorganisation}

For this, we assume that productivity follows a first-order Markov process and is potentially affected by reorganisation under private law (corporatisation) $\mu_{i t}$, outsourcing intensity with respect to services $\pi_{i t}=S_{i t} / L_{i t}+S_{i t}$, outsourcing intensity with respect to generation $\tau_{i t}=E_{i t} / R_{i t}$, and the sale of minority shares to the private sector $\eta_{i t}$

$$
\omega_{i t}=c+g\left(\omega_{i t-1}\right)+\alpha_{1} \pi_{i t}+\alpha_{2} \tau_{i t}+\alpha_{3} \mu_{i t-1}+\alpha_{4} \mu_{i t-1} \eta_{i t-1}+v_{i t} .
$$


Partial privatisation is conditional on corporatisation, i.e., only corporatised firms can sell minority shares to the private sector. This is accounted for by the interaction term $\mu_{i t-1} \eta_{i t-1}$. Corporatisation and partial privatisation are fundamental forms of reorganisation and potentially involve complex firm restructuring. Therefore, we assume that any effect on productivity takes at least one year to materialise and lag the corresponding variables by one period. Outsourcing, on the other hand, and the subcontracting of services, in particular, are more short-term oriented and could imply productivity gains within the same year. ${ }^{13}$

Note that the coefficients $\boldsymbol{\alpha}$ measure incremental effects and that the Markov process is particularly suited to identify organisational innovation. The coefficients capture changes in productivity related to the organisational structure, which can have two sources: (i) an initial effect from recent reorganisation if the firm changed its organisational structure between $t-1$ and $t$ and this has an immediate effect on its productivity; or (ii) gradual productivity growth if the firm chose an organisational structure some years ago but still obtains a yearly productivity gain from this (learning from reorganisation ${ }^{14}$ ).

The function $g\left(\omega_{i t-1}\right)$ is approximated through a third-order polynomial and the final estimation routine exploits the fact that any current shock to productivity $v_{i t}$ is uncorrelated with past and predetermined input values, i.e. $\mathbb{E}\left[v_{i t} \mid I_{i t-1}\right]=0$ where $I_{i t-1}=\left\{l_{i t}, k_{i t}, s_{i t-1}, l_{i t}^{2}, k_{i t}^{2}, s_{i t-1}^{2}, \ldots, d_{i j t}, d_{i f t}, \xi_{p}\right\}$. As a result, we obtain unbiased estimates for the vector $(\boldsymbol{\beta}, \boldsymbol{\gamma}, \boldsymbol{\alpha})$ and recover productivity $\omega_{i t}$ through (12).

\subsection{Permanent effect from organisational practise}

The vector $\boldsymbol{\alpha}$ measures intra-firm productivity growth over time from reorganisation, but not differences in productivity levels between firms with distinct organisational patterns. By construction, $\boldsymbol{\alpha}$ can only explain deviations of current productivity from past year productivity, hence productivity growth. For the $\alpha$ 's to be identified, we require variation over time in productivity. Consequently, the Markov process does not capture permanent differences in productivity levels between firms if these differences are stable in magnitude over time and if there is no switching between groups. ${ }^{15}$

\footnotetext{
${ }^{13}$ We control for outsourcing intensity in addition to the levels of $L$ and $S$ in the production function to assess productivity gains through substitution, since reorganisation often involves replacing internal staff with external staff. Moreover, outsourcing might not just produce direct effects on output through higher quality input, but also improve managerial practise. The manager could focus on core activities and optimise input usage therein, instead of allocating time to planning and monitoring peripheral activities.

14 The intuition is that the manager, who was hired when the firm was previously corporatised, each year produces new ideas on how to make the firm more productive. It will lead to an increase in productivity between $t-1$ and $t$, which is explained by the firm's status as 'corporatised firm'. See De Loecker (2013) for estimating a similar model for 'learning from exporting'.

15 Consider the following example. Firm A is fully state-owned and has a productivity level of $\omega_{A 2003}=1.5$ in year 2003, whereas firm B is partially privatised and has $\omega_{B 2003}=1.0$. In
} 
In this case, we are interested in knowing whether some organisational patterns are generally associated with higher productivity levels, even if we do not observe any switchers between patterns. Consequently, we complement the analysis by following Collard-Wexler and De Loecker (2015) and regress the log productivity estimates $\hat{\omega}_{i t}$ ex post on organisation (legal status $\mu_{i t-1}$, partial private ownership $\eta_{i t-1}$, outsourcing intensities $\tau_{i t}, \pi_{i t}$ ), a set of covariates $\boldsymbol{X}_{i t}$ (fuel usage, product space, firm size, population density $)^{16}$, and an error term $u_{i t}$.

$$
\hat{\omega}_{i t}=c+\gamma_{1} \pi_{i t}+\gamma_{2} \tau_{i t}+\gamma_{3} \mu_{i t-1}+\gamma_{4} \mu_{i t-1} \eta_{i t-1}+\boldsymbol{X}_{i t}+u_{i t}
$$

\section{Data}

We analyse all state-owned firms in the German energy and water sectors (NACE ID 35 and 36) between 2003 and 2014 with more than 10 employees and more than $200,000 \mathrm{~m}^{3}$ water treatment. This has not yet been done for lack of comprehensive microdata in this field. ${ }^{17}$ We fill this gap by constructing a unique panel dataset from a rich set of newly available data sources on German energy and water firms from the German Federal Statistical Office (Destatis). The dataset is composed of surveys from Energiestatistiken der amtlichen Statistik, a collection of state-owned firms' financial statements Jahresabschlüsse öffentlicher Fonds, Einrichtungen und Unternehmen, the German company register Unternehmensregister (URS) and data on settlement patterns published by the Federal Institute for Research on Building, Urban Affairs and Spatial Development (BBSR). A detailed description of each data source and the linkage strategy is provided in the appendix. Destatis considers firms as public/state-owned if government entities hold more than 50 per cent of the shares and/or votes.

\footnotetext{
2004, both firms keep their composition of owners unchanged and productivity is stable, i.e. $\omega_{A 2003}=\omega_{A 2004}=1.5$ and $\omega_{B 2003}=\omega_{B 2004}=1.0$ such that $\Delta \omega_{A t}=\Delta \omega_{B t}=0$. The vector $\boldsymbol{\alpha}$ in equation (13) would not identify any difference between fully and partially state-owned firms, since it requires variation over time in $\omega_{i t}$. The variation may either stem from variation in organisation (reorganisation, i.e., switchers) or from learning from reorganisation (see above). However, all other things being equal, in the present example the fully state-owned firm is more productive than the partially privatised one. This is what we call the permanent effect from organisational practise.

${ }^{16}$ Note that we already control for all of these measures, except firm size, in the initial production function estimation. Hence, we find that the majority of covariates do not contribute any further (significantly) to explaining productivity. Nevertheless, we included them in order to purge the organisational coefficients from any potential confounding influence.

17 There are single sector studies for German electricity DSOs and water companies based on data from the industrial association BDEW (e.g., Cullmann (2010), Zschille 2014, 2015). However, no dataset for multiproduct firms previously existed, even though most German energy and water firms are either vertically or horizontally integrated.
} 


\subsection{Sample Composition}

After eliminating observations with missing or clearly erroneous data, we obtain a final dataset of 2,325 firms, which are observed up to 12 years between 2003 and $2014(N=18,535)$. These are divided into 4 groups: mixed utilities $(n=$ $846)$, water-only utilities $(n=1170)$, electricity and gas utilities $(n=186)$, as well as heat and power generation plants $(n=123)$. Mixed utilities form the core sample of the study. They are multiproduct firms representing various horizontal and vertical output combinations. They should give an average picture of how productivity in the German public utility sector is affected by re-organisation since 2003. Water-only companies, by contrast, are considered as an example of firms with a homogeneous product space and few dynamics in the market structure. Pure electricity and gas utilities are treated distinctly in order to explore potential effects from market restructuring following liberalisation. ${ }^{18}$ Finally, heat and power plants are considered as an example of particularly capital-intensive industries. They are grouped together since they share important technologies.

The data is an unbalanced panel dataset, which raises the concern of an unobserved correlation between productivity and firms' entry/exit decision (Olley and Pakes, 1996). For instance, competition could drive low productivity firms out of the market or low-performing state-owned firms could be privatised and subsequently disappear from the sample. We argue that firm entry and exit is negligible in our case. First, drop-out rates are low. Less than $5 \%$ of the firms leave the sample before 2014. About $10 \%$ of the firms enter after 2003, with the majority entering in 2008. The observed mass entry in 2008 is the result of two occurrences that are unrelated to productivity. First, the revision in the classification of economic activities in 2008 changed the population from which firms were drawn. Notably, firms with their main activity in sewerage (NACE ID 38) became part of the surveys. The majority of new entrants are pure water companies, formerly classified as sewerage firms. The second group of new entrants is composed of electricity distributors. The electricity unbundling reforms in 2007 encouraged firms to reorganise network operation across all sectors in legal spin-offs, even though only large firms with more than 100,000 customers were legally obligated to do so.

\footnotetext{
${ }^{18}$ The electricity and gas sectors were exposed to EU-wide liberalisation in 1998, in contrast to the water and heat sector that remained local monopolies. Corporatisation and outsourcing in the liberalised industries might have been spurred by competitive pressure and, thus, have had more ample effects.
} 
Table 1: Sample composition

\begin{tabular}{lcccc}
\hline & water & gas & heat & electricity \\
\hline mixed utilities & $\mathrm{X}$ & $\mathrm{X}$ & $\mathrm{X}$ & $\mathrm{X}$ \\
water-only utilities & $\mathrm{X}$ & & & \\
electricity and gas utilities & & $\mathrm{X}$ & & $\mathrm{X}$ \\
heat and power plants & & & $\mathrm{X}$ & $\mathrm{G}$ \\
\hline $\begin{array}{l}\text { Notes: G = generation only. Transmission operators are excluded from } \\
\text { the analysis. All groups are mutually exclusive. }\end{array}$ \\
\hline
\end{tabular}

\subsection{Production}

The three main inputs are labour $L$, external services $S$, and capital $K$. Labour is measured by the wage bill to reflect differences in the composition of workforce, i.e., labour quality. This is particularly relevant when comparing multiproduct firms with different product mixes. The last row in table 2 compares hourly wages at the firm-level, showing that average wages are not the same across sectors. If hourly wages are correlated with labour quality, then workforce composition in electricity and gas supply differs from that in water supply and energy generation. ${ }^{19}$ External services are measured by expenditure and deflated using the PPI of the relevant service industries (NACE category M). Information on the capital stock and investments is taken from financial statements to construct a capital measure based on the perpetual inventory method with $K_{i t}=\left(1-\delta_{i}\right) K_{i t-1}+I_{i t}$, where both investments and the initial capital stock are deflated with the PPI of capital goods. The average depreciation rate $\delta_{i}$ is computed at the firm-level as the consumption of fixed capital divided by gross fixed capital. Output is measured by revenues minus expenditure on intermediate goods (material, procured energy and water). Table 2 provides summary statistics and shows that most firms are local small-sized suppliers, reflecting the municipality structure in Germany.

19 The rationale behind this is that the production process in electricity and gas supply changed fundamentally after liberalisation, which induced a shift in workforce composition towards more high-qualified personnel. Procurement in electricity supply is now much more complex because electricity is traded at the EEX and since OTC contracts are increasingly varied. The introduction of incentive regulation of the distribution networks requires experts on regulatory affairs. Further, new markets in the retail segment, such as energy efficiency consulting and marketing campaigns, rely on white collar workers. Consequently, firm-level wages in these sectors are higher. Measuring labour by the number of employees comes at the risk of obtaining productivity values that capture differences in labour quality rather than differences in performance. Fox and Smeets (2011) show that productivity dispersion among firms substantially decreases when the wage bill is used to measure labour input. 
Table 2: Summary statistics inputs and output

\begin{tabular}{|c|c|c|c|c|c|c|c|c|c|c|c|c|}
\hline & \multicolumn{3}{|c|}{ mixed utilities } & \multicolumn{3}{|c|}{ water } & \multicolumn{3}{|c|}{ electricity and gas } & \multicolumn{3}{|c|}{ heat and power plants } \\
\hline & med & mean & $\mathrm{sd}$ & med & mean & $\mathrm{sd}$ & med & mean & sd & med & mean & sd \\
\hline$L[$ mio $€]$ & 2.70 & 6.84 & 15.84 & 0.30 & 1.19 & 3.55 & 0.80 & 2.66 & 6.12 & 0.46 & 2.50 & 10.75 \\
\hline$S[$ mio $€]$ & 1.38 & 7.31 & 25.33 & 0.22 & 0.89 & 2.54 & 0.93 & 8.14 & 26.96 & 0.31 & 3.84 & 11.30 \\
\hline$K[$ mio $€]$ & 28.51 & 61.16 & 119.3 & 9.14 & 31.36 & 70.60 & 10.01 & 30.20 & 72.48 & 6.77 & 39.43 & 120.02 \\
\hline$Y[$ mio $€]$ & 10.39 & 28.48 & 66.01 & 1.32 & 4.42 & 11.2 & 6.69 & 22.12 & 47.85 & 2.05 & 13.21 & 38.35 \\
\hline $\mathrm{w}[€]$ & 33 & 33 & 7 & 30 & 30 & 8 & 34 & 35 & 11 & 30 & 30 & 9 \\
\hline$N$ & & 7,495 & & & 9,188 & & & 1,163 & & & 689 & \\
\hline
\end{tabular}

Notes: Hourly wages w are average gross wages computed from wage bill divided by number of hours worked.

Table 3 summarises characteristics of the production environment. We rely on information from the federal institute $B B S R$ to proxy for population density in the service supply areas. The institute sorts each German county according to its population pattern into one of the four categories: big cities, suburban areas, densely populated rural areas, and sparsely populated rural areas. County data is matched to firm-level data based on the location of the firm.

Table 3: Summary statistics production environment

\begin{tabular}{rrrr}
\hline \multicolumn{4}{c}{ Share of firms situated in... } \\
big cities & suburban & dense rural & sparse rural \\
\hline 0.07 & 0.51 & 0.23 & 0.19 \\
\hline
\end{tabular}

\subsection{Organisation}

\subsubsection{Outsourcing}

We distinguish two types of outsourcing: (I) outsourced services (e.g., maintenance work, customer relations); and (II) outsourced generation of energy and water. Between $92 \%$ and $98 \%$ of the firms rely on external services. Usage is lowest in water supply and highest among electricity and gas utilities. Figure 2a illustrates a vital growth in outsourcing intensity during 2003 and 2014. While average outsourcing intensity rose by 7 percentage points among mixed utilities, the ratio for electricity and gas utilities increased by 21 percentage points to $61 \%$ in $2014 .{ }^{20}$

20 The sharp increase after 2008 is in line with increased competition for end-consumers after the unbundling reforms in 2007, which triggered demand for marketing campaigns and strategic energy procurement. See footnote 19. 
Generation outsourcing is more heterogeneous across sectors. In 2014, $91 \%$ of state-owned electricity and gas firms purchased energy generated from third parties, whereas only two third of the water suppliers sourced water production externally (figure 1). This reflects the fact that state-owned firms own less than $30 \%$ of the electricity generation capacity and Germany imports virtually all of its natural gas (Monopolkommission, 2015). Water, on the other hand, is consumed locally and transportation over long distances is not efficient. The growing share of heat and power plants that at least partially outsource generation might look puzzling at first. However, it can be rationalised by the increasing use of process heat from manufacturing and waste combustion. Among those firms that outsource generation, outsourcing intensity further differs across sectors (figure $2 \mathrm{~b}$ ).

The most important message emerging from the graphs is that, both for services and generation, outsourcing intensity varies over the years. The variation in time is important to test our reorganisation hypothesis. Dynamics are stronger in the sectors affected by liberalisation and they are least pronounced in the water supply sector.

Figure 1: Share of firms buying energy or water from third parties

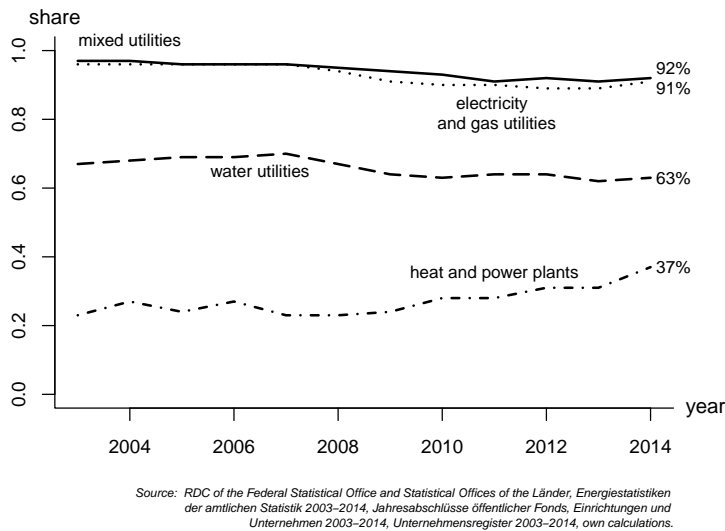


Figure 2: Outsourced services and generation

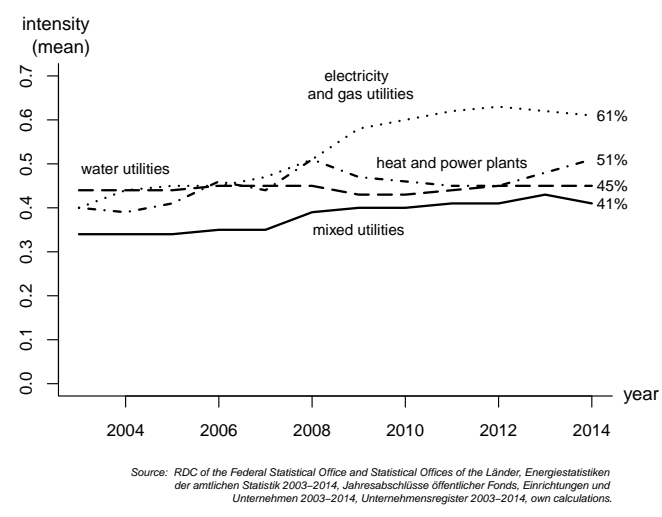

(a) Intensity of outsourced services

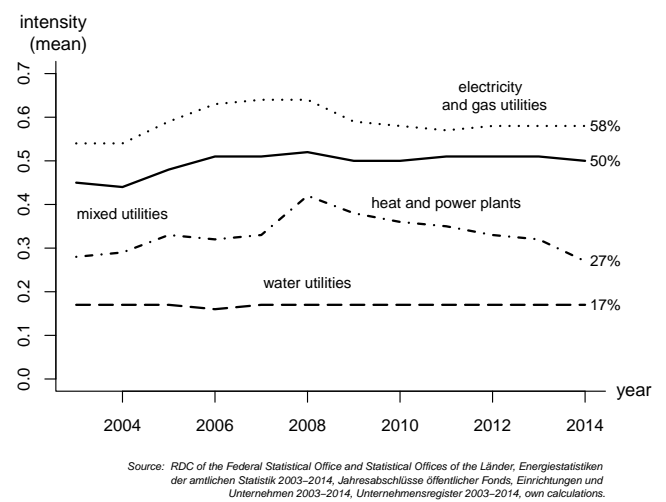

(b) Intensity of outsourced generation

\subsubsection{Corporatisation and partial privatisation}

Figure 3 summarises the legal structure and ownership composition. Organisation under private law is relatively common in the energy sectors (figure 3a). In 2014, roughly $93 \%$ of the electricity and gas firms were organised either as $G m b H$ or $A G$ and virtually all electricity and heat plants were corporatised (not displayed). By contrast, only $11 \%$ of the water firms chose a private legal status. The water sector, however, is peculiar in this respect as it disposes of a hybrid organisational form, an association of different municipalities called Zweckverband, which formally belongs to the public law but is open to private shareholders. This form of organisation is quite popular such that $40 \%$ of the water firms are organised as Zweckverbände.

While dynamics in corporatisation are rather weak with a 5 percentage point increase among mixed utilities, we see a more obvious trend towards nationalisation in figure $3 \mathrm{~b} .{ }^{21}$ The fraction of mixed utilities with private minority shares declined by 7 percentage points between 2003 and 2014. Again, the initial distribution is quite heterogeneous. While the private sector holds minority shares in roughly half of the heat and power plants, it is negligible in the water sector $(5 \%)$.

\footnotetext{
${ }^{21}$ Note that the private sector may only participate in firms organised under private law. Thus, the share of private participations is bounded by the fraction of corporatised firms.
} 
Figure 3: Legal form and partial privatisation
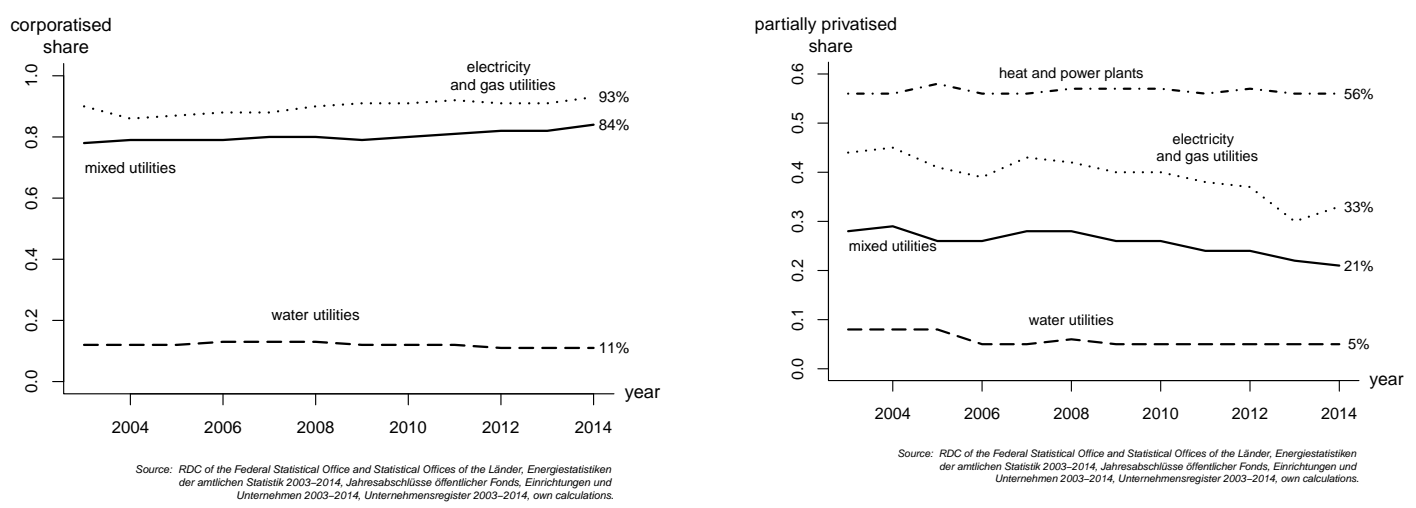

(a) share of firms organised under private law (b) share of firms with private participation

\subsubsection{Determinants for reorganisation}

Before commencing the main analysis, we explore the determinants for organisational innovation and potential correlations between the different reorganisation measures. Therefore, we regress outsourcing intensity on the remaining reorganisation measures (legal status, partial private ownership) and a set of covariates. These include firm size, proximity of external suppliers, labour costs (wages), investments, customer structure, fuel usage, and product space. Local availability of specialised suppliers is approximated through the $B B S R$ data on settlement structure, hypothesising that large cities offer a wider range of specialised suppliers than rural areas (Abraham and Taylor, 1996).

Table 4 shows the results for the main sample of mixed utilities. Private shareholders seem to foster outsourcing, while the legal status does not play a major role. Investment intensity is negatively correlated with outsourced generation, which illustrates the strategic decision between building up inhouse capacity and relying on external generation. We can confirm the proximity hypothesis for the availability of service suppliers, but not for generation. Rather, rural firms source more generation externally than those in larger cities. Surprisingly, firm-level wages cannot be identified as a major driver behind service outsourcing, suggesting that other motives than costs, e.g., access to external suppliers' expertise, could be more relevant in explaining service outsourcing among public utilities. This finding underlines the importance of studying alternative mechanisms, other than cost savings, through which outsourcing affects firm performance. As the focus of this model, outsourcing can also be conducted in search of productivity enhancing effects, through access to knowledge-intensive business services (KITS) and managerial focus on core activities, for instance. With regard to generation outsourcing, the picture is different. Wages seem to motivate outsourcing, even though the effect is very low in magnitude. 
Table 4: Determinants for reorganisation among mixed utilities

\begin{tabular}{|c|c|c|}
\hline & $\begin{array}{l}\text { outsourced } \\
\text { services } \pi\end{array}$ & $\begin{array}{c}\text { outsourced } \\
\text { generation } \tau\end{array}$ \\
\hline corporatised status $_{t-1}$ & $-0.001 \quad(0.007)$ & $0.000 \quad(0.006)$ \\
\hline 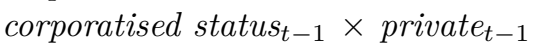 & $0.038^{* * *}(0.006)$ & $0.027^{* * *}(0.005)$ \\
\hline outsourced generation $_{t-1}$ & $-0.198^{* * *}(0.016)$ & \\
\hline outsourced services $_{t-1}$ & & $-0.131^{* * *}(0.010)$ \\
\hline${\text { investment } \text { intensity }_{t-1}}$ & -0.002 & $-0.022^{* * *}(0.007)$ \\
\hline wages $_{t-1}$ & $(0.000)$ & $0.001^{* * *}(0.000)$ \\
\hline size medium & -0.008 & $0.025^{* * *}(0.006)$ \\
\hline size large & $(0.009)$ & $0.074^{* * *}(0.007)$ \\
\hline elec: share residential supplyt-1 & -0.018 & $0.062^{* * *}(0.008)$ \\
\hline elec: share wholesale $_{t-1}$ & -0.016 & $-0.086^{* * *}(0.009)$ \\
\hline heat: share residential supplyt-1 & -0.010 & $-0.069^{* * *}(0.007)$ \\
\hline heat: share wholesale $_{t-1}$ & $0.055^{* *}(0.020)$ & $-0.095^{* * *}(0.016)$ \\
\hline suburban & $-0.060^{* * *}(0.010)$ & $0.055^{* * *}(0.008)$ \\
\hline dense rural & $-0.094^{* * *}(0.011)$ & $0.064^{* * *}(0.009)$ \\
\hline sparse rural & $-0.108^{* * *}(0.011)$ & $0.038^{* * *}(0.009)$ \\
\hline (Intercept) & $0.536^{* * *}(0.021)$ & $0.177^{* * *}(0.018)$ \\
\hline fuel usage & $\mathrm{X}$ & $\mathrm{X}$ \\
\hline product space & $\mathrm{X}$ & $\mathrm{X}$ \\
\hline customer structure & $\mathrm{X}$ & $\mathrm{X}$ \\
\hline time trend & $\mathrm{X}$ & $\mathrm{X}$ \\
\hline$R^{2}$ & 0.14 & 0.35 \\
\hline$N$ & 6,542 & 6,542 \\
\hline \multicolumn{3}{|c|}{$\begin{array}{l}\text { Notes: p-values: } 0{ }^{* * *}, 0.001, * *, 0.01, *, 0.05 \text {. Reference group: organisation under } \\
\text { public law (Eigenbetrieb). Organisations under public law in mixed ownership (private } \\
\text { shares) are ruled out by law. Investment intensity is measured as gross investments over } \\
\text { revenues. Firm size categories defined according to EC }(2003) \text {. }\end{array}$} \\
\hline
\end{tabular}

Table 8 in the appendix provides results by sector. Smaller firms increasingly rely on external services in water, electricity and gas supply, providing further evidence for the 'lack of expertise in KITS' hypothesis described in section 2.3. Electricity and gas supply are the only segments where corporatisation entails higher outsourcing levels. The water sector differs in various dimensions. First, private shareholders are associated with less generation outsourcing, for both corporatised firms and municipal associations. In addition, higher wages are negatively correlated with generation outsourcing, suggesting that in-house generation requires more qualified personnel. Third, the proximity hypothesis extends to generation, i.e., rural water companies purchase less water from other companies. 


\section{Results}

\subsection{Production technology}

Tables 5 below and 9 in the appendix report average output elasticities and returns to scale. Although average returns to scale are close to one, $97 \%$ of the mixed utilities and $96 \%$ of the water firms operate under decreasing returns to scale. ${ }^{22}$ Output elasticities vary between firms and sectors, which confirms the choice of a flexible translog production function and the separate estimation of sector-wise production technologies.

Table 5: Median output elasticities and returns to scale

\begin{tabular}{|c|c|c|c|c|c|}
\hline & \multirow{2}{*}{$\begin{array}{r}\text { labour } L \\
\text { med }\end{array}$} & \multirow{2}{*}{$\begin{array}{r}\text { capital } K \\
\text { med }\end{array}$} & \multirow{2}{*}{$\begin{array}{r}\text { external services } S \\
\text { med }\end{array}$} & \multicolumn{2}{|c|}{ returns to scale } \\
\hline & & & & med & share DRS \\
\hline mixed utilities & 0.502 & 0.243 & 0.201 & 0.943 & 0.97 \\
\hline water & 0.361 & 0.360 & 0.250 & 0.949 & 0.96 \\
\hline electricity/gas & 0.441 & 0.153 & 0.309 & 0.887 & 0.82 \\
\hline heat and power & 0.538 & 0.077 & 0.355 & 0.937 & 0.68 \\
\hline
\end{tabular}

\subsection{Productivity growth through reorganisation}

The estimated evolution of productivity following the Markov process in equation (13) is given in table 6. Water supply experiences the lowest annual changes in productivity $(\varphi=0.871)$, which is intuitive given that German water supply is characterised by local monopolies and a stable regulatory environment. Corporatisation has a small positive effect on future productivity in the main sample, but this relationship only holds for unlimited companies $(\mathrm{GmbH})$ and not for listed companies $(A G)$. Partial privatisation results in lower coefficients when compared to purely state-owned corporatised firms, although the difference is not statistically significant. Services subcontracting has a positive impact on productivity growth, while external generation does not seem to influence productivity growth. Zooming into the different sectors, we see that the relationship is reversed for electricity and gas firms, where generation outsourcing entails productivity gains, while service outsourcing does not affect productivity. Performance in water supply and among generation plants is not significantly influenced by reorganisation at all.

Overall immediate productivity gains from reorganisation are small. An increase in outsourcing intensity by 10 percentage points entails productivity growth of 0.4 percentages among mixed utilities and 0.3 percentages in electricity and gas supply.

${ }^{22}$ This is in line with the recent findings of Zschille (2016) who identifies cost advantages for local suppliers over regional suppliers in German water supply. 
Table 6: Productivity growth through reorganisation

\begin{tabular}{|c|c|c|c|c|}
\hline & $\begin{array}{c}\text { mixed utilities } \\
(1)\end{array}$ & $\begin{array}{l}\text { water } \\
(2)\end{array}$ & $\begin{array}{c}\text { electricity/gas } \\
\text { (3) }\end{array}$ & $\begin{array}{l}\text { heat/power } \\
\text { (4) }\end{array}$ \\
\hline productivity & $0.808^{* * *}(0.032)$ & $0.871^{* * *}(0.025)$ & $0.835^{* * *}(0.031)$ & $0.751^{* * *}(0.044)$ \\
\hline productivity $^{2}$ & $0.290^{* *}(0.099)$ & $-0.001 \quad(0.146)$ & $0.473^{* *}(0.145)$ & $-0.428^{* *}(0.131)$ \\
\hline productivity $^{3}$ & $-0.273^{* * *}(0.066)$ & $(0.837)$ & $-0.463^{* * *}(0.113)$ & $-0.301^{*}(0.135)$ \\
\hline $\operatorname{corp}(G m b H)$ & $0.003^{*}(0.001)$ & -0.001 & ) & \\
\hline $\operatorname{corp}(A G)$ & $0.002 \quad(0.004)$ & & & \\
\hline mun. association & & $(0.000)$ & & \\
\hline $\operatorname{corp}(G m b H) \times p r i v$ & $(0.001)$ & $(0.002)$ & & 00 \\
\hline $\operatorname{corp}(A G) \times$ priv & -0.005 & & $(0.000)$ & 0.00 \\
\hline mun association $\times$ priv & & $-0.0001 \quad(0.001)$ & & \\
\hline outsourced services & $0.040^{* * *}(0.008)$ & $0.002 \quad(0.002)$ & $(0.011)$ & -0.025 \\
\hline outsourced generation & $-0.004 \quad(0.003)$ & $(0.002)$ & $0.033^{*} \quad(0.016)$ & $(0.016)$ \\
\hline (Intercept) & $-0.009^{* *}(0.003)$ & -0.001 & -0.019 & $0.001 \quad(0.011)$ \\
\hline$R^{2}$ & 0.76 & 0.76 & 0.76 & 0.74 \\
\hline$N$ & 6,542 & 7,578 & 941 & 545 \\
\hline
\end{tabular}

Notes: Results from estimating the specification as given in (13). p-values: $0{ }^{* * *}, 0.001^{\prime * *} 0.01^{\prime *}, 0.05$. WHITE standard errors in parentheses. corp $=$ corporatised (organised under private law). priv $=$ minority shares held by private sector. In columns (5)-(8), $\mathrm{GmbH}$ and $\mathrm{AG}$ form a joint category 'corporatised'. Reference group for columns (1)-(6): organisation under public law (Eigenbetrieb). Reference group for columns (7)-(8): organisation under private law, fully publicly owned.

\subsection{Permanent effect from organisational practise}

While the Markov process focused on intra-firm productivity growth through reorganisation, equation (14) estimates differences in productivity levels between firms with distinct organisational structures. Results are given in table 7 . We do not find any significant effect for corporatisation, meaning that organisations under private law do not generally outperform organisations under public law. There are three possible reasons: (1) management autonomy plays a less crucial role for explaining state-enterprise performance than economic theory predicts; (2) legal autonomy does not necessarily imply actual autonomy, in the sense that political influence might also persist in state-owned firms organised under private law, e.g. through executive boards and selection of management staff; or (3) results could be interpreted the other way around. State-owned firms -whether organised under private law or public law- perform equally well, i.e. firms under public law do not suffer from any disturbing influence on (technical) ${ }^{23}$ productivity, despite being more closely connected to the political administration. However, this does not mean that individual

\footnotetext{
${ }^{23} \mathrm{It}$ is beyond the scope of this paper to compare the productivity of state-owned firms in achieving overall objectives, i.e. including both technical performance and the achievement of social goals. This paper only measures technical productivity in the tradition of the private sector.
} 
firms never profit from corporatisation. In the previous section, we have shown that those firms reorganising under private law between 2003 and 2014, on average did experience a positive impact on productivity.

The effect of private shareholders is ambiguous. For the main sample of mixed utilities, we do not find any significant difference, whereas in the electricity and gas sectors, firms with private shareholders are $6 \%$ less productive, on average, than purely state-owned firms. The difference is statistically significant at $<1 \%$ and confirms the indicative result from the Markov process (see column (3) in table $6)$. At the same time, electricity and gas supply are those sectors that experienced the largest shift in nationalisation, either through remunicipalisation or the new establishment of public utilities (see figure 3b). This suggests that this new generation of purely state-owned firms does not depend on the private sector for implicit knowledge transfer or the implementation of effective business routine, but rather it sometimes outperforms the latter. Interesting enough, this pattern does not hold for electricity generation in isolation and for heat supply. Here, privatesector participation increases average productivity by $7 \%$. Given that more than two thirds of installed power generation capacity is in the hands of the private sector (Monopolkommission, 2015), technical knowledge transfer might take a more vital role here, thus explaining the positive impact of private participations.

Finally, services outsourcing has a stable positive impact on productivity, ranging from $2 \%$ in water supply to $15 \%$ in the main sample. Production outsourcing plays a positive role among electricity and gas firms, which is consistent with the results from the Markov process. 
Table 7: Permanent effect from organisational practise

\begin{tabular}{|c|c|c|c|c|c|c|c|c|}
\hline \multirow{8}{*}{$\begin{array}{l}\operatorname{corp}(G m b H) \\
\text { corp }(A G) \\
\text { mun. association } \\
\text { corp }(G m b H) \times \text { priv } \\
\text { corp }(A G) \times \text { priv } \\
\text { mun. association } \times \text { priv } \\
\text { outsourced services } \\
\text { outsourced generation } \\
\text { (Intercept) }\end{array}$} & \multicolumn{2}{|c|}{ mixed utilities } & \multicolumn{2}{|c|}{ water } & \multicolumn{2}{|c|}{ electricity/gas } & \multicolumn{2}{|c|}{ heat/power } \\
\hline & 0.009 & $(0.006)$ & -0.008 & $(0.004)$ & 0.061 & $(0.032)$ & & \\
\hline & -0.016 & $(0.016)$ & -0.001 & $(0.002)$ & & & & \\
\hline & $\begin{array}{l}-0.001 \\
-0.034\end{array}$ & $\begin{array}{l}(0.004) \\
(0.022)\end{array}$ & 0.019 & $(0.017)$ & $-0.056^{* *}$ & $(0.021)$ & $0.072^{*}$ & $(0.031)$ \\
\hline & & & -0.001 & $(0.002)$ & & & & \\
\hline & $0.154^{* *}$ & $*(0.016)$ & $0.016^{*}$ & $(0.006)$ & $0.111^{* *}$ & $(0.034)$ & -0.058 & $(0.069)$ \\
\hline & 0.002 & $(0.013)$ & 0.003 & $(0.009)$ & $0.210^{* * *}$ & $(0.056)$ & -0.005 & $(0.076)$ \\
\hline & 0.001 & $(0.020)$ & -0.005 & $(0.012)$ & $-0.207^{* * *}$ & $(0.055)$ & $-0.197^{*}$ & $(0.087)$ \\
\hline fuel usage & $\mathrm{X}$ & & & & & & $\mathrm{X}$ & \\
\hline product space & $\mathrm{X}$ & & & & $\mathrm{X}$ & & $\mathrm{X}$ & \\
\hline firm size & $\mathrm{X}$ & & $\mathrm{X}$ & & $\mathrm{X}$ & & $\mathrm{X}$ & \\
\hline population density & $\mathrm{X}$ & & $\mathrm{X}$ & & $\mathrm{X}$ & & $\mathrm{X}$ & \\
\hline$R^{2}$ & 0.23 & & 0.02 & & 0.27 & & 0.17 & \\
\hline$N$ & 6,542 & & 7,578 & & 941 & & 545 & \\
\hline
\end{tabular}

Notes: Results from estimating the specification as given in equation (14). p-values: $0{ }^{\prime * * *}, 0.0011^{\prime * *}, 0.01$ '*, 0.05 . WHITE standard errors in parentheses. corp $=$ corporatised (organised under private law). priv $=$ minority shares held by private sector. In columns (5)-(8), GmbH and AG form a joint category 'corporatised'. Reference group for columns (1)-(6): organisation under public law (Eigenbetrieb). Reference group for columns (7)-(8): organisation under private law, fully publicly owned.

\section{Discussion}

\subsection{Selection into privatisation or corporatisation}

Economic theory suggests that poor performers might self-select into privatisation or corporatisation (see, e.g., Boycko et al., 1996). If private firms were inherently more productive at running certain businesses, then selling poor performing stateowned firms to the private sector could foster productivity growth and appeal to market-oriented politicians. Furthermore, privatisation could allow treasuries to save on transfer payments to loss-making firms.

Self-selection is accounted for in the model by means of the Markov process. ${ }^{24}$ As current $\omega_{i t}$ is regressed on past $\omega_{i t-1}$, the coefficients $\alpha_{3}, \alpha_{4}$ of the organisational variables $\mu_{i t-1}$ and $\eta_{i t-1}$ measure their contribution to productivity change between $t-1$ and $t$, i.e. the growth (or decline) in productivity since reorganisation took place. This is independent of the starting level. Even if firms had particularly low performance levels prior to partial privatisation (or corporatisation), this information is contained in $\omega_{i t-1}$ and does not affect the estimation of a subsequent change in productivity. Rather, $\alpha_{3}$ and $\alpha_{4}$ address the question of whether partial privatisation (corporatisation) have changed productivity for a given level of productivity:

${ }^{24}$ See De Loecker (2013) for originally discussing this issue with respect to selection into exporting. 
„Given hypothetical poor performance under state ownership, did private investors save the firm or did they make everything worse?". ${ }^{25}$

Furthermore, empirical evidence for the selection hypothesis in advanced economies is limited. Studies of the UK privatisations under Margaret Thatcher, for instance, suggest that other motives were more frequent, and that the government welcomed proceedings from privatising highly profitable firms to overcome public borrowing constraints (Yarrow, 1986; Florio, 2004). Among German public utilities, lossmaking as a result of poor performance has also been of little concern. Instead, profits from public utilities are an important source of cross-subsidisation for other public services, such as public transport.

\subsection{Selection into outsourcing}

In section 5, we argue that it is reasonable to expect effects from outsourcing on productivity to happen (if at all) within a short time horizon, which is why we measure the effect of outsourcing intensity on contemporaneous productivity rather than on future (next year) productivity. This raises the concern of another endogeneity issue, where those firms, which incurred high productivity gains from other sources, self-select into outsourcing. Productivity gains stemming from other sources would then be wrongly attributed to increased outsourcing. To explore whether self-selection into outsourcing is a concern, we run the model again and lag outsourcing intensity for services by one, respectively two, periods. Thereby, we consider the decision of the firm made before any productivity gains (or losses) took place. Results are given in column (1) and (2) of table 11 in the appendix. The positive effect of a 10 percentage point increase in outsourcing intensity remains significant in both settings. The magnitude of the productivity gain decreases from 0.4 per cent in the same year to 0.2 after one year and 0.02 per cent after two years. Results are also confirmed when looking at permanent effects from organisation.

\subsection{Interactions between organisational strategies}

So far, the model analyses outsourcing in isolation from major restructuring (partial privatisation, corporatisation). However, the development of new business routines following corporatisation and changes in ownership might also involve modifications in outsourcing behaviour. Section 6.3.3 explored the determinants for outsourcing intensity and showed that in the main sample of mixed utilities, private

${ }^{25}$ Finding a negative effect for partial privatisation further backs a unidirectional mechanism and speaks against the hypothesis of selection. Poor initial performance levels of state-owned firms should make it easier for private investors to induce productivity growth in the following years, when compared to a state-owned firm that is already highly efficient prior to privatisation. If there was selection into privatisation and the private sector was inherently more productive, we would expect $\Delta_{\eta}=\hat{\alpha}_{4}-\hat{\alpha}_{3}$ to be positive, which is not the case. 
owners favour higher outsourcing ratios and that firms organised under private law displayed higher outsourcing rates in the electricity and gas sectors. To disentangle the channels through which productivity is affected, we augment the baseline model and additionally include interactions between different organisational strategies in the productivity process. Results are given in column (4) of table 11 in the appendix for the main sample and column (3) of table 12 in the appendix for electricity and gas supply.

Despite the observation that partially privatised firms source more externally than fully state-owned firms, we do not see any distinct effects on productivity among mixed utilities. Rather, the magnitude of productivity gains from service outsourcing seems to be independent of legal status and ownership composition. Much as in the baseline model, generation outsourcing does not have any effect at all.

In electricity and gas supply, however, the augmented model provides some important additional insights. First, we see that a positive effect from service outsourcing among fully state-owned firms organised under public law is nearly completely offset by the negative impact among fully state-owned firms organised under private law. For this reason, we do not find any effect from service outsourcing in the baseline model (see column (3) in tables 6 and 7). The higher outsourcing intensity among the latter group actually seems to produce a negative impact on productivity growth, which suggests some over-saturation effect. This is also supported by the observation that corporatised firms in mixed ownership source less externally and do not suffer from a negative impact on performance. Concerning generation outsourcing, the pattern is reversed. Private shareholders are associated with a negative effect of generation outsourcing on productivity, which is particularly surprising given the fact that electricity generation capacity in Germany is predominantly owned by the private sector. We would rather expect positive spill-overs from preferential procurement. Thus, the positive impact of generation outsourcing on productivity in the baseline model is mediated by fully state-owned corporatised firms.

\subsection{Generation outsourcing in electricity and gas supply}

Electricity and gas supply are the only sectors where outsourced generation had a significant effect on productivity. Given very limited domestic natural gas resources in Germany, gas suppliers have no choice but to externally source gas production (apart from biogas solutions). The strongly positive result for outsourced generation could then mask inherent productivity gains in the gas sector unrelated to reorganisation. To verify this, we run the estimation again on a reduced sample, where we exclude all pure gas firms to ensure that the firms considered indeed have a true choice for subcontracting generation or not. The reduced sample is composed of pure electricity firms and mixed electricity-gas firms. Results are provided in column (1) of table 11 in the appendix. Importantly, the positive effect from generation 
outsourcing is robust to excluding pure gas firms and only marginally decreases in magnitude when compared to the full sample.

\subsection{Pass-through}

The way generation outsourcing intensity is measured raises another concern. Generation outsourcing is defined in monetary terms as expenditure for procurement over revenues. In section 4 , we assume that retail prices proportionally reflect procurement unit costs, i.e. pass-through is constant across firms and time (assumption A2). Only then can changes in output intensity be attributed to changes in volumes and not to price effects. What if this assumption does not hold? Is there reason to believe that the positive relationship between increased outsourcing intensity merely reflects a price effect, i.e. some firms charge higher markups than others, thus appearing to be more 'sales' productive? Our findings do not support this hypothesis. To see this, assume that some firms simply raise the markup from one period to another while keeping volumes constant, i.e., despite decreasing expenditure for outsourced generation, they maintain retail prices and thus their level of revenues. Consequently, observed outsourcing intensity would decrease. Since we find a positive impact from increasing outsourcing intensity on productivity, this would actually mean that firms with higher markups are less (sales) productive.

\subsection{Time-varying production technology}

The rise in outsourced services between 2003 and 2014 might not only affect productivity but change the production technology as a whole. This is partially accounted for by the translog specification, which allows output elasticities to vary by input levels and over time. To increase flexibility and assess any changes over time, we re-estimate the model with an augmented production function including a time-trend $t \in\{1,2,3, .$.$\} in the first-order input coefficients:$

$$
\begin{aligned}
y_{i t}= & c+\beta_{l} l_{i t}+\beta_{s} s_{i t}+\beta_{k} k_{i t}+0.5 \beta_{l l} l_{i t}^{2}+0.5 \beta_{s s} s_{i t}^{2}+0.5 \beta_{k k} k_{i t}^{2} \\
& +\beta_{l s} l_{i t} s_{i t}+\beta_{l k} l_{i t} k_{i t}+\beta_{k s} k_{i t} s_{i t} \\
& +\beta_{l t} l_{i t} t+\beta_{s t} s_{i t} t+\beta_{k t} k_{i t} t \\
& -\sum_{F} \gamma_{f} \bar{p}_{f t} d_{i f t}+\sum_{J} \gamma_{j} \bar{p}_{j t} d_{i j t}+\xi_{p} \\
& +\omega_{i t}+\epsilon_{i t} .
\end{aligned}
$$

Table 10 in the appendix summarises average output elasticities for the augmented model. The interacted time-trend coefficients turn out to be not significant in the main sample and output elasticities remain roughly unchanged when compared to 
the baseline model in table $9 .{ }^{26}$ For comparison, we also re-estimate the model in the electricity and gas sectors, where outsourcing dynamics are most pronounced (see figure 2a). Here, we find that average output elasticities increased for labour and external services, while it decreased for capital. Indeed, the time coefficient for capital is negative and significant $\left(\beta_{k t}=-0.021\right)$, which results in decreasing average output elasticities over time (see figure $4 \mathrm{~b}$ ). This probably reflects the growing importance of personnel-intensive business services such as marketing, procurement, and regulatory affairs after liberalisation to the detriment of the 'old business model' with a purely technical focus and reduced customer management. Turning to the effect of reorganisation on productivity, column (3) in table 11 and column (2) in table 12 in the appendix globally confirm findings from the baseline model. The effect from partial privatisation is reinforced, though, such that it now exerts a significantly negative impact on productivity.

\section{Conclusion}

Public enterprises have not disappeared from European economies. They are still prevalent in many sectors of general interest such as energy provision, transportation, and postal services. Moreover, some countries like Germany are experiencing a renaissance of public sector involvement at the local level. Since 1998, however, liberalisation and the emergence of new technologies required public enterprises to adapt to new market environments and engage in organisational innovation.

The present paper evaluates three elements of organisational innovation among 2,325 state-owned German energy and water firms between 2003 and 2014: (i) outsourcing; (ii) corporatisation; and (iii) selling minority shares to the private sector. Performance is measured as total factor productivity derived in a structural production function framework and estimated applying a control function approach. Since energy and water firms are traditionally multiproduct firms, we suggest a method to account for different input and output prices at the product level.

Results suggest that outsourcing and corporatisation are positively correlated with productivity, while partial privatisation does not increase productivity. Rather, fully state-owned firms outperform firms in mixed ownership. The reason could be conflicting owner interests (multiple-principals problem) and frustration among public managers when their intrinsic public service motivation is crowded out by inflexible business rules. The paper contributes to scarce empirical evidence on contemporary public enterprises in advanced economies and sheds light on the link between reorganisation and firm performance.

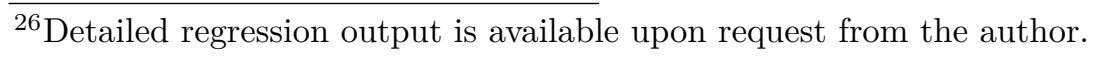




\section{References}

Abraham, K., Taylor, S., 1996. Firms' Use of Outside Contractors: Theory and Evidence. Journal of Labor Economics 14 (3), 394-424.

Ackerberg, D., Caves, K., Frazer, G., 2015. Identification Properties of Recent Production Function Estimators. Econometrica 83 (6), 2411-2451.

Aharoni, Y., 1981. Performance Evaluation of State-Owned-Enterprises: A Process Perspective. Management Science 27 (11), 1340-1347.

Antonietti, R., 2016. From Outsourcing to Productivity, Passing through Training: Microeconometric Evidence from Italy. Industry and Innovation 23 (5), 407-425.

Aw, B. Y., Roberts, M., Xu, D., 2011. R\&D Investment, Exporting, and Productivity Dynamics. American Economic Review 101 (4), 1312-1344.

Bartel, A., Harrison, A., 2005. Ownership versus Environment: Disentangling the Sources of Public-Sector Inefficiency. Review of Economics and Statistics 87 (1), $135-147$.

Bengtsson, L., Dabhilkar, M., 2009. Manufacturing Outsourcing and its Effect on Plant Performance - Lessons for KIBS Outsourcing. Journal of Evolutionary Economics 19 (2), 231-257.

Bertero, E., Rondi, L., 2000. Financial Pressure and the Behaviour of Public Enterprises under Soft and Hard Budget Constraints: Evidence from Italian Panel Data. Journal of Public Economics 75 (1), 73-98.

BMWi, 2017. Energiedaten. Tech. rep., German Federal Ministry for Economic Affairs and Energy, Berlin.

Bénabou, R., Tirole, J., 2003. Intrinsic and Extrinsinc Motivation. The Review of Economic Studies 70 (3), 489-520.

Borghi, E., Del Bo, C., Florio, M., 2016. Institutions and Firms' Productivity: Evidence from Electric Distribution in the EU. Oxford Bulletin of Economics and Statistics 78 (2), 170-196.

Boycko, M., Shleifer, A., Vishny, R., 1996. A Theory of Privatisation. Economic Journal 106 (435), 309-319.

Celen, A., 2013. Efficiency and Productivity (TFP) of the Turkish Electricity Distribution Companies: An Application of Two Stage (DEA\&Tobit) Analysis. Energy Policy 63 (9), 300-310. 
Clò, S., Ferraris, M., Florio, M., 2017. Ownership and Environmental Regulation: Evidence from the European Electricity Industry. Energy Economics 61 (1), 298312.

Collard-Wexler, A., De Loecker, J., 2015. Reallocation and Technology: Evidence from the US Steel Industry. American Economic Review 105 (1), 131-171.

Crewson, P., 1997. Public-Service Motivation: Building Empirical Evidence of Incidence and Effect. Journal of Public Administration Research and Theory 7 (4), 499-518.

Cullmann, A., 2010. Benchmarking and Firm Heterogeneity: A Latent Class Analysis for German Electricity Distribution Companies. Empirical Economics 42 (1), $147-169$.

Cullmann, A., Nieswand, M., Rechlitz, J., 2017. Productive Efficiency and Ownership When Market Restructuring Affects Production Technologies. DIW Discussion Paper 1641.

Cullmann, A., Nieswand, M., Seifert, S., Stiel, C., 2016. A (Re)Municipalization Trend among Energy Utilities: Truth or Myth? DIW Economic Bulletin 6 (20), $227-232$.

De Loecker, J., 2013. Detecting Learning by Exporting. American Economic Journal: Microeconomics 5 (3), 1-21.

De Loecker, J., Warzynski, F., 2012. Markups and Firm-Level Export Status. American Economic Review 102 (6), 2437-2471.

Doraszelski, U., Jaumandreu, J., 2013. R\&D: Estimating Endogenous Productivity. Review of Economic Studies 80 (4), 1338-1383.

EC, 2003. Commission Recommendation of 6 May 2003 Concerning the Definition of Micro, Small and Medium-Sized Enterprises. Commission Recommendation C(2003) 1422, European Commission, Brussels.

Estrin, S., Pérotin, V., 1991. Does Ownership Always Matter? International Journal of Industrial Organization 9 (1), 55-72.

Fariñas, J., López, A., Martín-Marcos, A., 2014. Assessing the Impact of Domestic Outsourcing and Offshoring on Productivity at the Firm Level. Applied Economics 46 (15), 1814-1828.

Farsi, M., Filippini, M., 2009. An Analysis of Cost Efficiency in Swiss Multi-Utilities. Energy Economics 31 (2), 306-315. 
Florio, M., 2004. The Great Divestiture. Evaluating the Welfare Impact of the British Privatizations 1979-1997. MIT Press.

Florio, M., 2013. Network Industries and Social Welfare. The Experiment that Reshuffled European Utilities. Oxford University Press.

Florio, M., 2014. Contemporary Public Enterprises: Innovation, Accountability, Governance. Journal of Economic Policy Reform 17 (3), 201-208.

Fox, J., Smeets, V., 2011. Does Input Quality Drive Measured Differences in Firm Productivity? International Economic Review 52 (4), 961-989.

Francois, P., 2000. 'Public service motivation' as an Argument for Government Provision. Journal of Public Economics 78 (3), 275-299.

Francois, P., 2007. Making a Difference. RAND Journal of Economics 38 (3), 714732 .

Fumagalli, E., Garrone, P., Grilli, L., 2007. Service Quality in the Electricity Industry: The Role of Privatization and Managerial Behavior. Energy Policy 35 (12), $6212-6224$.

Gilley, M., Rasheed, A., 2000. Making More by Doing Less: An Analysis of Outsourcing and its Effects on Firm Performance. Journal of Management 26 (4), $763-790$.

Gottschalk, W., 2012. Strukturen und Organisation von Stadtwerken. In: Bräunig, D., Gottschalk, W. (Eds.), Stadtwerke. Grundlagen, Rahmenbedingungen, Führung und Betrieb. Nomos. Baden-Baden.

Gregg, P., Grout, P., Ratcliffe, A., Smith, S., Windmeijer, F., 2011. How Important is Pro-Social Behaviour in the Delivery of Public Services? Journal of Public Economics 95 (7-8), 758-766.

Grönblom, S., Willner, J., 2014. Organisational Form and Individual Motivation: Public Ownership, Privatisation and Fat Cats. Journal of Economic Policy Reform 17 (3), 267-284.

Hall, D., Lobina, E., Terhorst, P., 2013. Re-Municipialisation in the Early TwentyFirst Century: Water in France and Energy in Germany. International Review of Applied Economics 27 (2), 193-214.

Hood, C., 1995. The "New Public Management" in the 1980s: Variations on a Theme. Accounting, 20 (2-3), 93-109.

Houston, D., 2000. Public Service Motivation: A Multivariate Test. Journal of Public Administration Research and Theory 10 (4), 713-727. 
Kettl, D., 1997. The Global Revolution in Public Management: Driving Themes, Missing Links. Journal of Policy Analysis and Management 16 (3), 446-462.

Kumbhakar, S., 1996. Estimation of Cost Efficiency with Heteroscedasticity: An Application to Electricity Utilities. Journal of the Royal Statistical Society 45 (3), 319-335.

Kumbhakar, S. C., Hjalmarsson, L., 1998. Relative Performance of Public and Private Ownership under Yardstick Competition: Electricity Retail Distribution. European Economic Review 42 (1), 97-122.

Kwoka, J., 2005. The Comparative Advantage of Public Ownership: Evidence from U.S. Electric Utilities. The Canadian Journal of Economics 38 (2), 622-640.

Laffont, J.-J., Martimort, D., 1997. The Firm as a Multicontract Organization. Journal of Economics \& Management Strategy 6 (2), 201-234.

Laffont, J.-J., Tirole, J., 1991. Privatization and Incentives. Journal of Law, Economics, \& Organization 7 (Special Issue), 84-105.

López, A., 2014. Outsourcing and Firm Productivity: A Production Function Approach. Empirical Economics 47 (3), 977-998.

Monopolkommission, 2015. Sondergutachten 71: Energie 2015: Ein wettbewettbewerbliches Marktdesign für die Energiewende. Tech. rep., Monpolkommission, Bonn.

Morrison Paul, C., Yasar, M., 2009. Outsourcing, Productivity, and Input Composition at the Plant Level. The Canadian Journal of Economics / Revue canadienne d'Economique, 42 (2), 422-439.

Olley, G., Pakes, A., 1996. The Dynamics of Productivity in the Telecommunications Equipment Industry. Econometrica 64 (6), 1263-1297.

Pargendler, M., Musacchio, A., Lazzarini, S., 2013. In Strange Company: The Puzzle of Private Investment in State-Controlled Firms. Cornell International Law Journal 46 (3), 569-610.

Polidori, P., Teobaldelli, D., 2013. Prosocial Behavior in the Production of Publicly Provided Goods and Services: An Overview. International Journal of Applied Economics 27 (2), 285-296.

Rainey, H., 1982. Reward Preferences among Public and Private Managers: In Search of the Service Ethics. American Review of Public Administration 16 (4), 288-302. 
Roodhooft, F., Warlop, L., 1999. On the Role of Sunk Costs and Asset Specifcity in Outsourcing Decisions: a Research Note. Accounting, Organizations and Society 24 (4), 363-369.

Saal, D., Parker, D., Weyman-Jones, T., 2007. Determining the Contribution of Technical Change, Efficiency Change and Scale Change to Productivity Growth in the Privatized English and Welsh Water and Sewerage Industry: 1985-2000. Journal of Productivity Analysis 28 (1-2), 127-139.

Shleifer, A., Vishny, R. W., 1994. Politicians and Firms. The Quarterly Journal of Economics 109 (4), 995-1025.

Statistisches Bundesamt, 2015. Öffentliche Wasserversorgung und öffentliche Abwasserentsorgung - Strukturdaten zur Wasserwirtschaft - 2013. Tech. rep., Statistisches Bundesamt.

Stiel, C., 2015. Official Data on German Utilities (Energiestatistiken der amtlichen Statistik) 2003-2012. DIW Data Documentation Series 12 (80).

Stiel, C., Cullmann, A., Nieswand, M., 2017. Do Private Utilities Outperform Local Government-Owned Utilities? Evidence from German Retail Electricity. German Economic Review forthcoming.

Vining, A. R., Boardman, A. E., 1992. Ownership versus Competition: Efficiency in Public Enterprise. Public Choice 73 (2), 205-239.

Windrum, P., Reinstaller, A., Bull, C., 2009. The Outsourcing Productivity Paradox: Total Outsourcing, Organisation Innovation, and Long Run Productivity Growth. Journal of Evolutionary Economics 19 (2), 197-229.

Yarrow, G., 1986. Privatization in Theory and Practice. Economic Policy 1 (2), $323-364$.

Zschille, M., 2014. Nonparametric Measures of Returns to Scale: An Application to German Water Supply. Empirical Economics 47 (3), 1029-1053.

Zschille, M., 2015. Consolidating the Water Industry: An Analysis of the Potential Gains from Horizontal Integration in a Conditional Efficiency Framework. Journal of Productivity Analysis 44 (1), 97-114.

Zschille, M., 2016. Cost Structure and Economies of Scale in German Water Supply. DIW Discussion Paper 1576.

\section{A. Appendix}




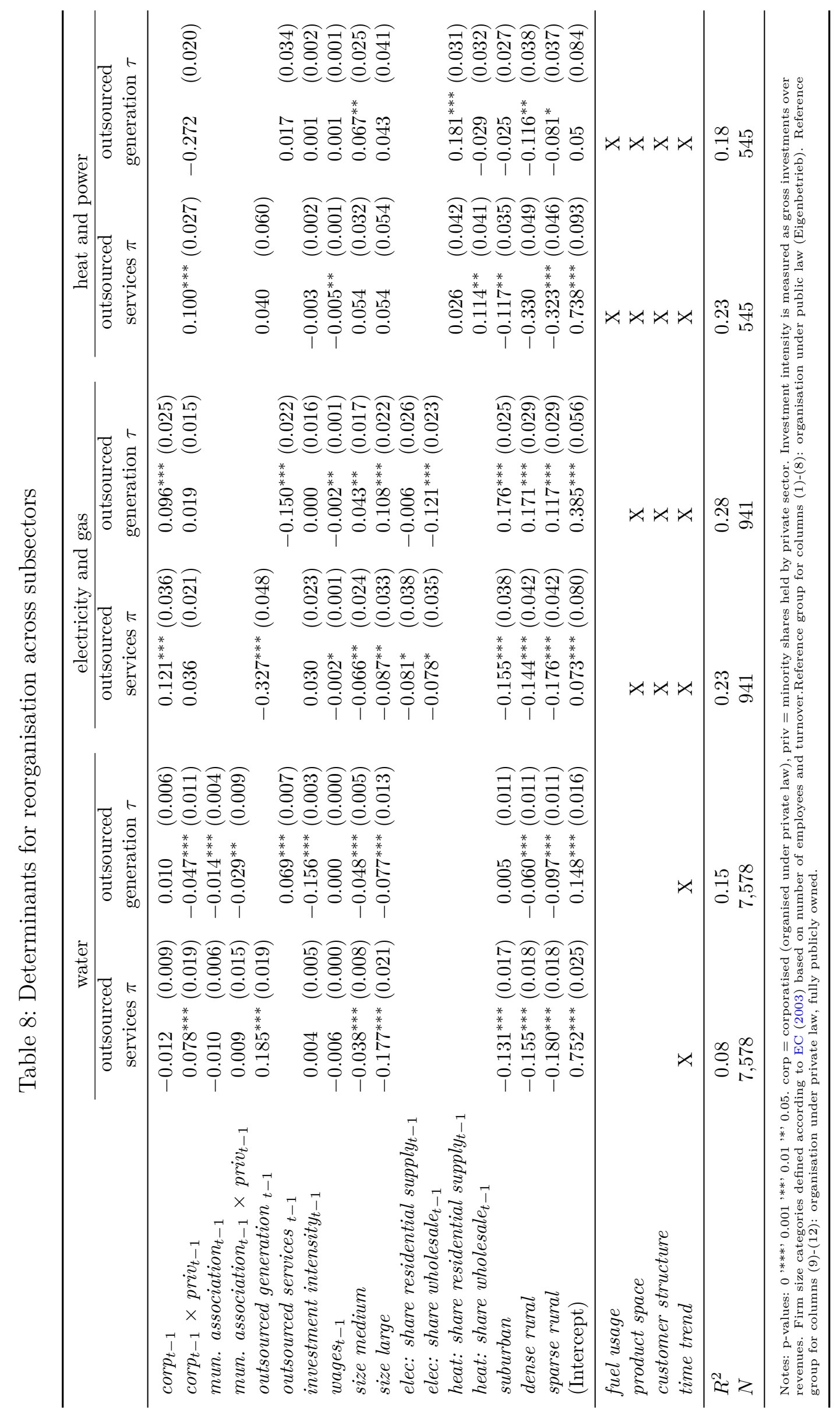


Table 9: Mean output elasticities and mean returns to scale

\begin{tabular}{|c|c|c|c|c|c|c|c|c|}
\hline & \multicolumn{2}{|c|}{ labour $L$} & \multicolumn{2}{|c|}{ capital $K$} & \multicolumn{2}{|c|}{ external services $S$} & \multicolumn{2}{|c|}{ returns to scale } \\
\hline & mean & $\mathrm{sd}$ & mean & $\mathrm{sd}$ & mean & $\mathrm{sd}$ & mean & $\mathrm{sd}$ \\
\hline mixed util & 0.487 & $(0.129)$ & 0.238 & $(0.074)$ & 0.213 & $(0.116)$ & 0.938 & $(0.04)$ \\
\hline water & 0.337 & $(0.161)$ & 0.363 & $(0.110)$ & 0.248 & $(0.138)$ & 0.948 & $(0.03)$ \\
\hline electricity/gas & 0.401 & $(0.263)$ & 0.145 & $(0.087)$ & 0.364 & $(0.314)$ & 0.910 & $(0.09)$ \\
\hline heat and power & 0.499 & $(0.352)$ & 0.083 & $(0.106)$ & 0.375 & $(0.256)$ & 0.957 & $(0.10)$ \\
\hline
\end{tabular}

Table 10: Output elasticities and returns to scale under time trend

\begin{tabular}{|c|c|c|c|c|c|c|c|c|}
\hline & \multicolumn{2}{|c|}{ labour $L$} & \multicolumn{2}{|c|}{ capital $K$} & \multicolumn{2}{|c|}{ external services $S$} & \multicolumn{2}{|c|}{ returns to scale } \\
\hline & mean & $\mathrm{sd}$ & mean & $\mathrm{sd}$ & mean & $\mathrm{sd}$ & mean & $\mathrm{sd}$ \\
\hline mixed utilities & 0.486 & $(0.141)$ & 0.228 & $(0.062)$ & 0.219 & $(0.144)$ & 0.933 & $(0.03)$ \\
\hline electricity/gas & 0.370 & $(0.255)$ & 0.202 & $(0.123)$ & 0.333 & $(0.281)$ & 0.888 & $(0.07)$ \\
\hline
\end{tabular}

Figure 4: Output elasticities in electricity and gas supply

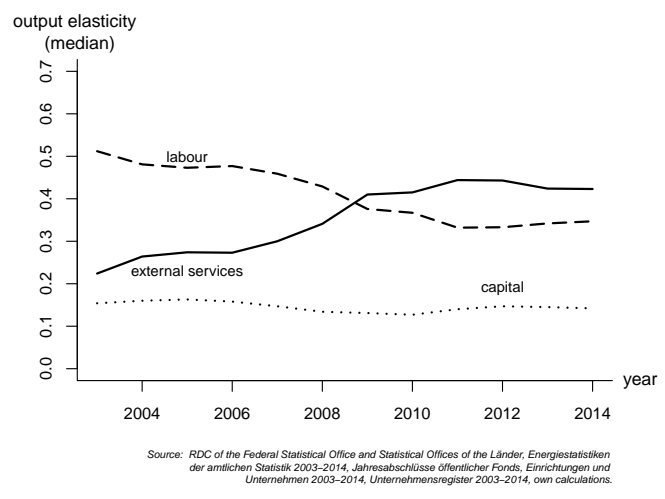

(a) baseline model

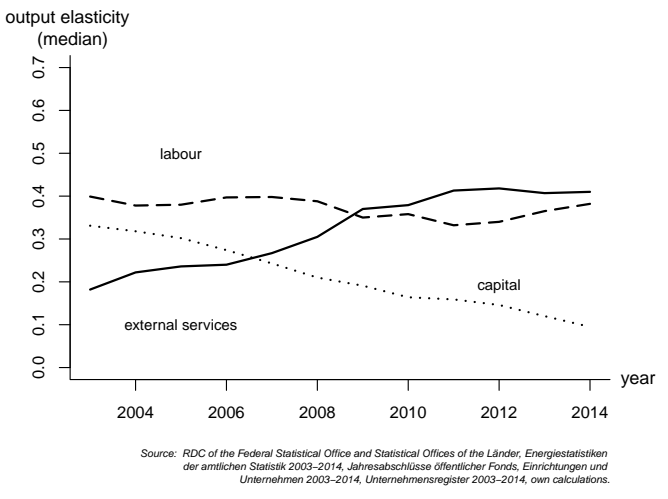

(b) time trend model 
Table 11: Sensitivity analyses among mixed utilities

\begin{tabular}{|c|c|c|c|c|c|}
\hline & $\begin{array}{c}\text { service } \\
\text { outsourcing } \\
(\mathrm{t}-1) \\
(1) \\
\end{array}$ & $\begin{array}{c}\text { service } \\
\text { outsourcing } \\
(\mathrm{t}-2) \\
(2) \\
\end{array}$ & $\begin{array}{l}\text { time trend } \\
\text { production } \\
(3)\end{array}$ & $\begin{array}{l}\text { interac } \\
\text { organis }\end{array}$ & $\begin{array}{l}\text { ctions } \\
\text { sation } \\
\text { 4) }\end{array}$ \\
\hline \multicolumn{6}{|c|}{ Productivity growth through reorganisation } \\
\hline $\operatorname{corp}(G m b H)$ & $0.001 \quad(0.001)$ & $0.002^{* *}(0.001)$ & 0.001 & -0.008 & $(0.007)$ \\
\hline $\operatorname{corp}(A G)$ & $0.000 \quad(0.003)$ & $0.001 \quad(0.001)$ & $0.002 \quad(0.002)$ & -0.008 & $(0.008)$ \\
\hline $\operatorname{corp}(G m b H) \times p r i v$ & $0.000 \quad(0.001)$ & $0.000 \quad(0.000)$ & $0.000 \quad(0.001)$ & -0.012 & $(0.006)$ \\
\hline $\operatorname{corp}(A G) \times$ priv & $-0.004 \quad(0.005)$ & $-0.005^{*}(0.002)$ & $-0.005 \quad(0.003)$ & $-0.018^{*}$ & $(0.008)$ \\
\hline serv & $0.018^{* * *}(0.004)$ & $0.006^{*} \quad(0.002)$ & $0.037^{* * *}(0.004)$ & 0.015 & $(0.029)$ \\
\hline prod & $-0.003 \quad(0.003)$ & $-0.006^{*} \quad(0.002)$ & $-0.001 \quad(0.003)$ & 0.002 & $(0.012)$ \\
\hline serv $\times$ prod & & & & -0.016 & $(0.029)$ \\
\hline $\operatorname{serv} \times \operatorname{corp}$ & & & & $0.026^{*}$ & $(0.011)$ \\
\hline $\operatorname{serv} \times \operatorname{corp} \times p r i v$ & & & & $0.029^{* *}$ & $(0.009)$ \\
\hline prod $\times$ corp & & & & 0.001 & $(0.008)$ \\
\hline prod $\times \operatorname{corp} \times$ priv & & & & 0.001 & $(0.008)$ \\
\hline (Intercept) & $(0.002)$ & $(0.002)$ & $-0.014^{* * *}(0.002)$ & 0.006 & $(0.006)$ \\
\hline$R^{2}$ & 0.75 & 0.75 & 0.78 & 0.75 & \\
\hline$N$ & 6,542 & 5,697 & 6,542 & 6,542 & \\
\hline \multicolumn{6}{|c|}{ Permanent effect from organisational practise } \\
\hline $\operatorname{corp}(G m b H)$ & $0.007 \quad(0.005)$ & $0.010^{*} \quad(0.004)$ & $(0.004)$ & -0.027 & $(0.024)$ \\
\hline $\operatorname{corp}(A G)$ & $-0.011 \quad(0.012)$ & $-0.001 \quad(0.007)$ & $-0.003 \quad(0.007)$ & -0.043 & $(0.027)$ \\
\hline $\operatorname{corp}(G m b H) \times$ priv & $-0.003 \quad(0.003)$ & $-0.004 \quad(0.002)$ & $-0.005 \quad(0.003)$ & -0.030 & $(0.021)$ \\
\hline $\operatorname{corp}(A G) \times$ priv & $-0.028 \quad(0.016)$ & $-0.024^{* *}(0.008)$ & $-0.023^{* *}(0.008)$ & $-0.063^{*}$ & $(0.028)$ \\
\hline serv & $0.081^{* * *}(0.012)$ & $0.033^{* * *}(0.008)$ & $0.093^{* * *}(0.010)$ & 0.082 & $(0.055)$ \\
\hline prod & $0.006 \quad(0.012)$ & $-0.004 \quad(0.009)$ & $-0.004 \quad(0.009)$ & 0.027 & $(0.042)$ \\
\hline serv $\times$ prod & & & & -0.074 & $(0.093)$ \\
\hline $\operatorname{serv} \times \operatorname{corp}$ & & & & $0.089^{*}$ & $(0.041)$ \\
\hline $\operatorname{serv} \times \operatorname{corp} \times$ priv & & & & $0.083^{* *}$ & $(0.031)$ \\
\hline prod $\times$ corp & & & & 0.007 & $(0.032)$ \\
\hline prod $\times \operatorname{corp} \times$ priv & & & & -0.006 & $(0.028)$ \\
\hline (Intercept) & $0.031^{*} \quad(0.016)$ & $0.008 \quad(0.013)$ & $(0.013)$ & 0.031 & $(0.027)$ \\
\hline fuel usage & $\mathrm{X}$ & $\mathrm{X}$ & $\mathrm{X}$ & $\mathrm{X}$ & \\
\hline product space & $\mathrm{X}$ & $\mathrm{X}$ & $\mathrm{X}$ & $\mathrm{X}$ & \\
\hline firm size & $\mathrm{X}$ & $\mathrm{X}$ & $\mathrm{X}$ & $\mathrm{X}$ & \\
\hline population density & $\mathrm{X}$ & $\mathrm{X}$ & $\mathrm{X}$ & $\mathrm{X}$ & \\
\hline$R^{2}$ & 0.12 & 0.08 & 0.18 & 0.23 & \\
\hline$N$ & 6,542 & 5,697 & 6,542 & 6,542 & \\
\hline
\end{tabular}


Table 12: Sensitivity analyses in electricity and gas supply

\begin{tabular}{|c|c|c|c|}
\hline & $\begin{array}{l}\text { without gas } \\
\text { firms } \\
(1) \\
\end{array}$ & $\begin{array}{l}\text { time trend } \\
\text { production } \\
(2)\end{array}$ & $\begin{array}{c}\text { interactions } \\
\text { organisation } \\
(3)\end{array}$ \\
\hline \multicolumn{4}{|c|}{ Productivity growth through reorganisation } \\
\hline $\begin{array}{l}\text { corp } \\
\text { corp } \times \text { priv } \\
\text { serv } \\
\text { prod } \\
\text { serv } \times \text { prod } \\
\text { serv } \times \text { corp } \\
\text { serv } \times \text { corp } \times \text { priv } \\
\text { prod } \times \text { corp } \\
\text { prod } \times \text { corp } \times \text { priv } \\
(\text { Intercept }) \\
R^{2} \\
N\end{array}$ & $\begin{array}{cc}0.006 & (0.008) \\
-0.011 & (0.006) \\
-0.011 & (0.012) \\
0.041^{* *} & (0.015)\end{array}$ & $\begin{array}{cc}0.008 & (0.006) \\
-0.012^{*} & (0.005) \\
0.016 & (0.010) \\
0.037^{* *} & (0.013)\end{array}$ & $\begin{array}{cc}0.043 & (0.026) \\
-0.021 & (0.023) \\
0.118^{* * *}(0.027) \\
0.029 & (0.040) \\
-0.033 & (0.060) \\
-0.109^{* * *}(0.028) \\
0.017 & (0.023) \\
0.031 & (0.037) \\
-0.002 & (0.032) \\
-0.068^{* *} & (0.021) \\
0.76 & \\
941 & \end{array}$ \\
\hline \multicolumn{4}{|c|}{ Permanent effect from organisational practise } \\
\hline $\begin{array}{l}\text { corp } \\
\text { corp } \times \text { priv } \\
\text { serv } \\
\text { prod } \\
\text { serv } \times \text { prod } \\
\text { serv } \times \text { corp } \\
\text { serv } \times \text { corp } \times \text { priv } \\
\text { prod } \times \text { corp } \\
\text { prod } \times \text { corp } \times \text { priv } \\
(\text { Intercept })\end{array}$ & $\begin{array}{cc}0.065 & (0.033) \\
-0.048^{*} & (0.020) \\
0.029 & (0.046) \\
0.177^{* *} & (0.063)\end{array}$ & $\begin{array}{rr}0.050^{*} & (0.022) \\
-0.052^{* *} & (0.018) \\
0.095^{* * *} & (0.027) \\
0.040 & (0.047)\end{array}$ & $\begin{array}{lr}0.051 & (0.067) \\
0.040 & (0.070) \\
0.319^{* * *} & (0.071) \\
0.067 & (0.103) \\
0.011 & (0.169) \\
-0.245^{* * *} & (0.064) \\
0.062 & (0.063) \\
0.244^{*} & (0.096) \\
-0.222^{*} & (0.106) \\
-0.235^{* *} & (0.081)\end{array}$ \\
\hline $\begin{array}{l}\text { fuel usage } \\
\text { product space } \\
\text { firm size } \\
\text { population density } \\
R^{2} \\
N\end{array}$ & $\begin{array}{c}\mathrm{X} \\
\mathrm{X} \\
\mathrm{X} \\
\mathrm{X} \\
0.22 \\
724\end{array}$ & $\begin{array}{c}\mathrm{X} \\
\mathrm{X} \\
\mathrm{X} \\
\mathrm{X} \\
0.19 \\
941\end{array}$ & $\begin{array}{c}\mathrm{X} \\
\mathrm{X} \\
\mathrm{X} \\
\mathrm{X} \\
0.29 \\
941\end{array}$ \\
\hline
\end{tabular}




\section{B. Data appendix}

\section{B.1. Energiestatistiken}

The survey data on German energy and water firms Energiestatistiken consists of 9 separate surveys that are conducted each year by the regional statistical offices. Cumulatively, these surveys cover all German firms with NACE ID 35 and 36 above a certain threshold (more than 10 employees/1MW installed capacity/200,000m3 water treatment). Firms are legally obligated to respond. The data is used by the Federal Statistical Office to publish aggregate figures on the German energy and water sector on a regular basis.

Anonymised microdata at firm-level is available for the years 2003 to 2014 and can be analysed in remote access at the research data centres of the statistical offices.

Each survey covers distinct aspects of German energy and water supply, collecting, for instance, data on physical inputs, output, customer structure, fuel use, network losses, installed capacity or investments (see Stiel, 2015, for details). The panel dataset used for the analysis was constructed merging the surveys listed in table 13 for the period between 2003 and 2014 with firm ID and year as identifiers.

\section{B.2. Jahresabschlüsse öffentlicher Fonds, Einrichtungen und Unternehmen}

The official dataset Jahresabschlüsse öffentlicher Fonds, Einrichtungen und Unternehmen collects financial statements of all German firms where public authorities hold more than 50 per cent of the shares and/or votes. It covers all sectors of the German economy. Anonymised microdata is available for the years 1998 to 2014 and can be accessed at the research data centres of the regional statistical offices. Information (in German) is given on the webpage of the research data centres http: //www. forschungsdatenzentrum.de/bestand/jahresabschluss/index. asp.

\section{B.3. Unternehmensregister (URS)}

The company register Unternehmensregister (URS) kept by the statistical offices allows for deriving unique firm IDs to merge the above datasets (http:// www. forschungsdatenzentrum.de/bestand/urs/index.asp). It contains further information on tax group relationships, which, in theory, would allow for the identification of affiliated firms that belong to the same enterprise group. However, the quality of the tax data is limited. 
Table 13: List of surveys from Energiestatistiken used

\begin{tabular}{|c|c|c|}
\hline survey code & original title & english translation \\
\hline $43211-077$ & $\begin{array}{l}\text { Investitionserhebung bei Unternehmen } \\
\text { der Energieversorgung, Wasserversorgung, } \\
\text { Abwasser- und Abfallentsorgung, Beseitigung } \\
\text { von Umweltverschmutzungen }\end{array}$ & $\begin{array}{l}\text { investment structure of firms in the en- } \\
\text { ergy, water, sewerage and waste man- } \\
\text { agement sectors }\end{array}$ \\
\hline 43211-076 & $\begin{array}{l}\text { Investitionserhebung bei Betrieben der } \\
\text { Energieversorgung, } \text { Wasserversorgung, } \\
\text { Abwasser- und Abfallentsorgung, Beseitigung } \\
\text { von Umweltverschmutzungen }\end{array}$ & $\begin{array}{l}\text { investment structure of plants in the en- } \\
\text { ergy, water, sewerage and waste man- } \\
\text { agement sectors }\end{array}$ \\
\hline $43221-081$ & $\begin{array}{l}\text { Kostenstrukturerhebung bei Unternehmen } \\
\text { der Energieversorgung, Wasserversorgung, } \\
\text { Abwasser- und Abfallentsorgung, Beseitigung } \\
\text { von Umweltverschmutzungen }\end{array}$ & $\begin{array}{l}\text { cost structure of firms in the energy, } \\
\text { water, sewerage and waste management } \\
\text { sectors }\end{array}$ \\
\hline $43331-083$ & $\begin{array}{l}\text { Erhebung über Stromabsatz und Erlöse } \\
\text { der Stromversorgungsunternehmen und } \\
\text { Stromhändler }\end{array}$ & $\begin{array}{l}\text { survey on electrity sales and quantities } \\
\text { delivered by electricity traders }\end{array}$ \\
\hline $43371-070$ & $\begin{array}{l}\text { Erhebung über die Stromeinspeisung bei Net- } \\
\text { zbetreibern }\end{array}$ & $\begin{array}{l}\text { electricity feed-in of distribution net- } \\
\text { work operators }\end{array}$ \\
\hline $43312-66 \mathrm{~N}$ & $\begin{array}{l}\text { Erhebung über die Elektrizitätsversorgung der } \\
\text { Netzbetreiber }\end{array}$ & $\begin{array}{l}\text { general survey on electricity distribu- } \\
\text { tion network operators }\end{array}$ \\
\hline $43411-064$ & $\begin{array}{l}\text { Erhebung über die Erzeugung, Bezug, Ver- } \\
\text { wendung und Abgabe von Wärme }\end{array}$ & $\begin{array}{l}\text { survey on the generation, purchase, use } \\
\text { and supply of heat }\end{array}$ \\
\hline $43111-065$ & $\begin{array}{l}\text { Monatsbericht bei Betrieben der Energie- und } \\
\text { Wasserversorgung }\end{array}$ & $\begin{array}{l}\text { monthly report on energy and water } \\
\text { plants }\end{array}$ \\
\hline $43311-66 \mathrm{~K}$ & $\begin{array}{l}\text { Monatsbericht über die Elektrizitäts- und } \\
\text { Wärmeerzeugung der Stromerzeugungsanla- } \\
\text { gen für die allgemeine Versorgung }\end{array}$ & $\begin{array}{l}\text { monthly report on electricity and heat } \\
\text { generation in power plants }\end{array}$ \\
\hline
\end{tabular}

\section{B.4. Settlement data from BBSR}

The Federal Institute for Research on Building, Urban Affairs and Spatial Development $(B B S R)$ collects information on spatial development in Germany and provides a classification system for comparing the settlement structure of German counties. It may be accessed through the webpage (in German): http://www . bbsr . bund. de/BBSR/DE/Raumbeobachtung/Raumabgrenzungen/Kreistypen4/kreistypen . html. The settlement data is merged to the panel dataset using the official community identification number distributed to all municipalities by the regional statistical offices (Amtlicher Gemeindeschlüssel). 